\title{
Human impact on the hydrology of the Andean páramos
}

\author{
Wouter Buytaert $^{\mathrm{a}, \mathrm{b}, *}$, Rolando Célleri ${ }^{\mathrm{b}, \mathrm{c}}$, Bert De Bièvre ${ }^{\mathrm{b}}$, Felipe Cisneros ${ }^{\mathrm{b}}$, \\ Guido Wyseure ${ }^{\text {a }}$, Jozef Deckers ${ }^{\text {a }}$, Robert Hofstede ${ }^{\mathrm{d}, \mathrm{e}}$ \\ a Division of Soil and Water Management, Katholieke Universiteit Leuven, Belgium \\ b Programa para el Manejo del Agua y del Suelo, Universidad de Cuenca, Ecuador \\ ${ }^{\mathrm{c}}$ Hydraulics Laboratory, Katholieke Universiteit Leuven, Belgium \\ ${ }^{\mathrm{d}}$ EcoPar, Quito, Ecuador \\ e Institute for Biodiversity and Ecosystem Dynamics, University of Amsterdam, The Netherlands
}

Received 7 February 2006; accepted 9 June 2006

Available online 24 July 2006

\begin{abstract}
This paper analyses the problems involved in the conservation and management of the hydrological system of the South American páramo. The páramo consists of a collection of neotropical alpine grassland ecosystems covering the upper region of the northern Andes. They play a key role in the hydrology of the continent. Many of the largest tributaries of the Amazon basin have their headwaters in the páramo. It is also the major water source for the Andean highlands and a vast area of arid and semi-arid lowlands, where páramo water is used for domestic, agricultural and industrial consumption, and the generation of hydropower. Recently, the páramo is increasingly used for intensive cattle grazing, cultivation, and pine planting, among others. These activities, as well as global phenomena such as climate change, severely alter the hydrological regime. A review on the state of knowledge of its hydrology is given in a first part. In a second part, the impact of human activities and climate change on the hydrology of the páramo is discussed.
\end{abstract}

(C) 2006 Elsevier B.V. All rights reserved.

Keywords: hydrology; wetlands; management; land use; mountain environments

\section{Introduction}

Mountains fulfil important ecological and economic functions for the surrounding lowlands, including the sustenance of ecological minimum flows, and water production for agriculture, food production and hydropower generation. In arid regions, the total contribution of mountainous areas to catchment discharge may represent

\footnotetext{
* Corresponding author. Now at: Environmental Sciences, Lancaster University, LA1 4YQ Lancaster, UK.

E-mail address: w.buytaert@lancaster.ac.uk (W. Buytaert).
}

as much as $95 \%$ of the total flow (Liniger et al., 1998). Globally it is estimated that about $40 \%$ of the global population lives in watersheds of rivers originating in the planet's different mountain regions (Beniston, 2003). Discharge from many mountainous areas is characterized by a disproportionally large contribution with regard to the catchment area, as well as a high reliability and low coefficient of variation (Viviroli et al., 2003; Messerli et al., 2004; Viviroli and Weingartner, 2004).

The hydrological importance of mountain areas stands in sharp contrast with their vulnerability. In many locations, human land use rapidly encroaches on natural areas, resulting in an increased stress on the ecosystem and 
environmental deterioration. In addition to ecological and geomorphological deterioration, such as loss of habitat and diversity or increased erosion, these land use changes may have a thorough impact on the water cycle. Changes in glacier dynamics, snowcover, soil properties and vegetation, landcover and land management alter the water regulation capacity of mountainous catchments in different ways. Increased consumption and extraction may result in lower base flows. On a larger scale, climate change has similar effects: a higher energy input enhances the hydrological cycle and may increase precipitation and evapotranspiration. Glacier melt and an upward shift of the snowline affect discharge rates and timing (Foster, 2001; IPCC, 2001; Meybeck, 2004).

Due to the difficult monitoring circumstances, and therefore the relative scarcity of long range datasets, our knowledge of runoff generation in mountain areas is limited, in particular in the tropics and the subtropics. As important, limiting our knowledge is the complex topography, vegetation and soils, and the rapid spatial and temporal changes in climatic parameters (Beniston, 2003; Meybeck et al., 2005).

This complexity renders the sustainable management of mountainous water resources particularly challenging (Liniger et al., 1998), particularly in the Andean páramos. The páramo, both referred to in singular and in plural páramos, is a collection of neotropical alpine ecosystems within the grassland biome or Orobiome. It covers the upper region of the northern Andes between the upper forest line (about $3500 \mathrm{~m}$ altitude) and the permanent snow line (about $5000 \mathrm{~m}$ ) (Castaño, 2002; Hofstede et al., 2003) (Fig. 1). The páramo is the major water provider for the Andean highlands of Venezuela, Colombia and Ecuador, extensive parts of the adjacent lowlands, and the arid coastal plains of North Peru. The water quality is excellent, and the rivers descending from the páramo provide a high and sustained base flow. On the other hand, human activities, such as cultivation, intensification of livestock grazing, Pinus plantations and tourism, increased recently in the páramo. These activities may significantly alter the hydrological behaviour of the páramo, affecting directly the water supply function. Like other mountain ranges, the páramo is subject to global climate change. As these problems are becoming critical, effective land use planning is necessary to ensure optimal water supply to cities and rural areas. This planning requires a good understanding of the páramo hydrology that can support major decisions that have to be taken in the near future.

This paper gives an overview of the current state of scientific knowledge of the hydrology of the páramo, identifying contradictions and major scientific gaps in our

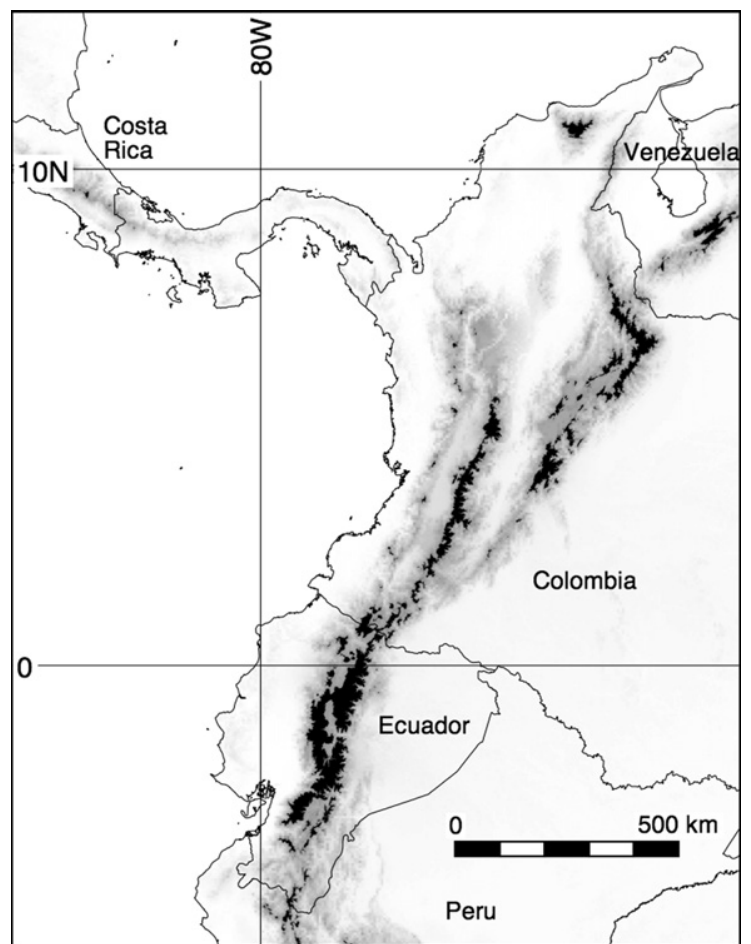

Fig. 1. Approximate extension (in black) of the páramos in the northern Andes of Venezuela, Colombia, Ecuador and Peru, with a small, isolated patch in Costa Rica.

understanding of the hydrological system. In a second part, we review the current knowledge of the impact of human activities on the hydrology of the páramo, based on available information on the páramo as well as information from similar hydrological systems.

\section{The Andean páramos}

The Andean páramos consist of accidented, mostly glacier formed valleys and plains with a large variety of lakes, peat bogs and wet grasslands intermingled with shrublands and low-statured forest patches (Fig. 2). They cover the upper parts of the northern Andes, roughly between $11^{\circ}$ north and $8^{\circ}$ south latitude. As such, they form a discontinuous belt between the Cordillera de Merida in Venezuela and the Huancabamba depression in northern Peru. The southernmost páramos, occurring in southern Ecuador and northern Peru, have a slightly different graminaceous vegetation and may locally be known as "Jalca". Additionally, two separate páramo complexes exist, one in Costa Rica and one in the Sierra Nevada de Santa Marta, Colombia (Hofstede et al., 2003; Kappelle and Horn, 2005). Similar biomes are found in other continents. Tropical alpine grasslands similar to the páramo are abundantly present in the afroalpine belt, 


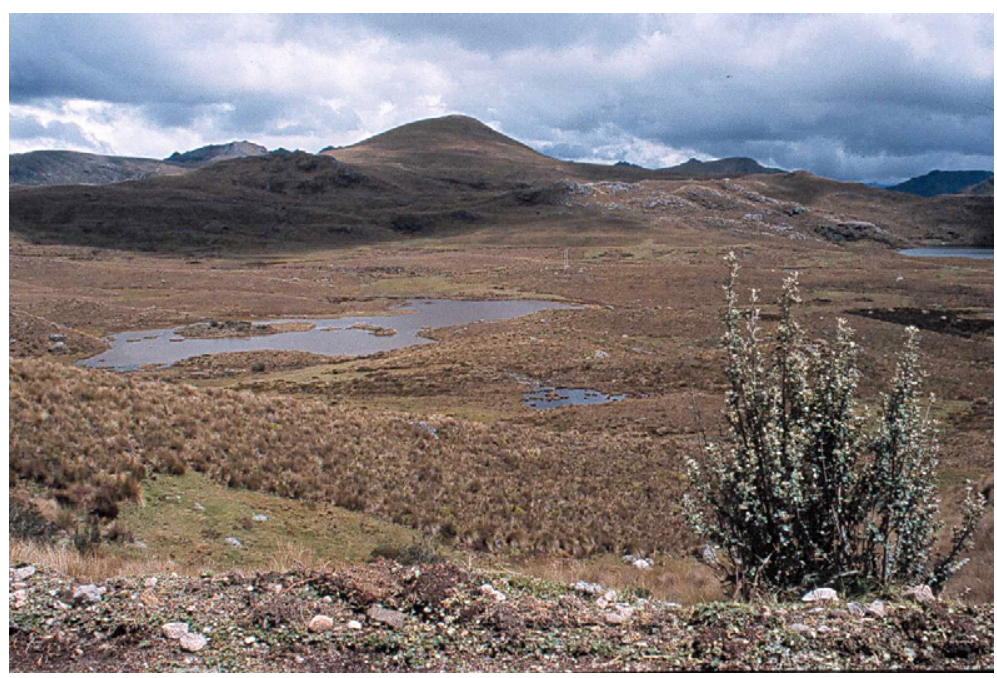

Fig. 2. Typical view of the south Ecuadorian páramo (Soldados valley, El Cajas National Park, south Ecuador).

stretching from Ethiopia and Uganda to Kenya, Tanzania and South Africa (Hedberg, 1964, 1992). To a smaller extent, they occur in New Guinea and Indonesia (Hofstede et al., 2003). While most analyses are also valid for these regions, this study concentrates on the South American páramos. The total area covered by páramo is estimated between 35,000 (Hofstede et al., 2003) and 77,000 $\mathrm{km}^{2}$ (Dinerstein et al., 1995). This discrepancy is primarily due to uncertainties in the lower limit of the páramo. The natural forest limit is severely altered by human activity (logging, intensive grazing), which makes the difference between natural and artificial grasslands difficult to distinguish.

The isolated and fragmented occurrence of the páramo over the Andean highlands promotes high speciation and an exceptionally high endemism. The páramo hosts about 5000 different plant species. About $60 \%$ of these species are endemic, adapted to the specific physio-chemical and climatic conditions, such as the low atmospheric pressure, intense ultra-violet radiation, and the drying effects of wind. The vegetation consists mainly of tussock grasses, ground rosettes, dwarf shrubs cushion plants and conspicuous giant rosettas, such as Espeletia sp. and Puya sp. (Acosta-Solís, 1984; Vargas and Zuluaga, 1986; Luteyn et al., 1992; Hofstede, 1995d). In some areas, a clear altitudinal vegetation gradient is present. In the subpáramo, 3000-3500 m altitude, mosaics with shrubs and small trees alternate with grasslands. Extensive cloud forests may develop at certain places, consisting of small, twisted and gnarled trees with small and thick, notophyllous leaves and many epiphytes. In the proper páramo $(3500-4500 \mathrm{~m})$, grasslands dominate and patches of woody species such as Polylepis sp. and Gynoxys sp. occur only in sheltered locations and along water streams. The superpáramo is a narrow zone with scarce vegetation between the grass páramo and the snow line. In all vegetation belts, azonal vegetation types (cushion bogs, mires, aquatic vegetation) occur in flat, perhumid areas (Cleef, 1981).

Despite the remoteness and the cold and wet climate, human activity in the páramo is not uncommon. Human presence in the upper Andes goes back to prehistorical times (Chepstow-Lusty et al., 1996) but in many cases, activities were limited to extensive grazing by free ranging animals. It is supposed that these activities do not pose a significant pressure on the ecosystem. Some regions, however, are characterised by intensive cultivation of potatoes and beans, and these practices are still increasing rapidly, despite the technical difficulties involved in cultivation of the páramo. Access is difficult and most soils have to be drained intensively as they tend to be severely waterlogged, but population growth, increased urbanisation and soil degradation in the lower valleys have pushed the agricultural limit upwards into the páramo. Finally, tourism has become an important aspect of páramo management, which may improve local livelihoods and economic development. Wide concern is rising that the intensification and amplification of these activities interferes with its environmental services.

\section{The climate}

The páramo features a typical tropical high mountain climate. Due to its location close to the equator, the daily solar radiation is almost constant throughout the year. This constancy sharply contrasts with the daily cycle, which is 

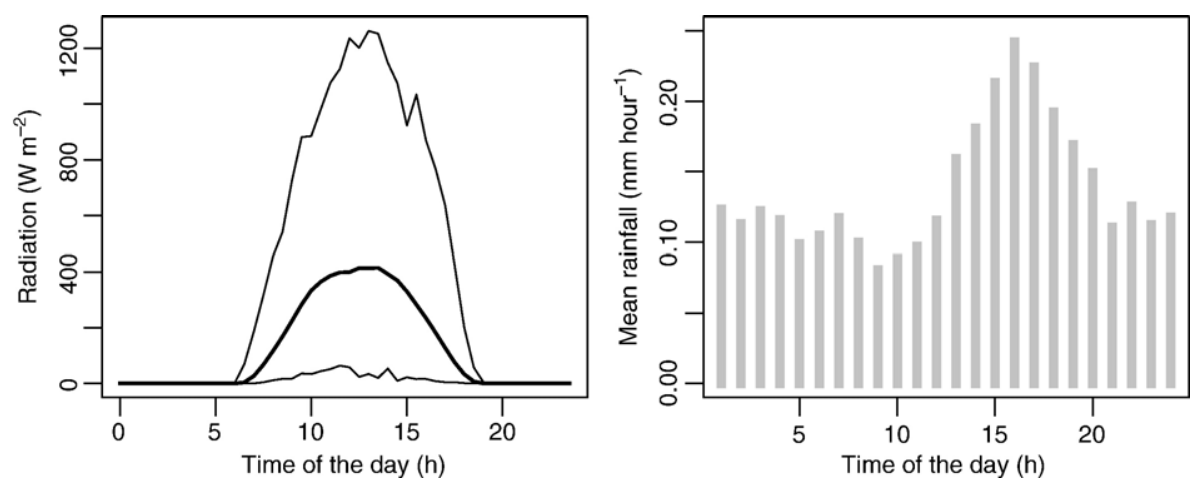

Fig. 3. Daily variation in average, minimum and maximum radiation (left) and in average daily rainfall (right) in the páramo of Chanlud, south Ecuador (3800 m).

quite marked (Fig. 3). Intraday temperature variations of more than $20{ }^{\circ} \mathrm{C}$ are common ("summer every day and winter every night”, Hedberg, 1964). Sarmiento (1986) gives a comprehensive overview of the meteorologic data from several weather stations in the páramo of Venezuela, Colombia and Ecuador. The climate of the páramos of Costa Rica is described by Herrera (2005). Figs. 3 and 4 show data from the páramo of Machangara, south Ecuador (Buytaert, 2004). These typical temperature variations determine the role of frost and snow. Due to the lack of seasonality, the snow line is very sharp and constant throughout the year. Between 4000 and $5000 \mathrm{~m}$ altitude, frost occurs frequently during the nighttime but daily maxima are sufficiently high to prevent snow and ice accumulation. Below $4000 \mathrm{~m}$ altitude, frost does not occur regularly and when it occurs, it is restricted to a few hours before sunrise. Nevertheless, ice and glacier activity upslope of the páramo belt may sustain important water supplies, especially in dryer páramos (e.g., Cotopaxi, Chimborazo).

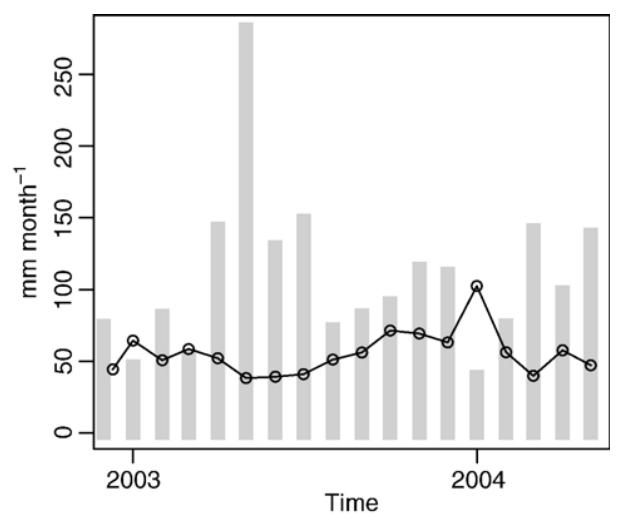

Fig. 4. Monthly rainfall (bars) and potential evapotranspiration (line) in the páramo of Machangara near Cuenca $(3800 \mathrm{~m})$.
Temperature variability in the páramo depends primarily on two aspects: the altitudinal gradient and the air humidity, determined by the local climate. The lapse rate, which is the change in average temperature with altitude, is typically between 0.6 and $0.7{ }^{\circ} \mathrm{C}$ $100 \mathrm{~m}^{-1}$ (van der Hammen and Hooghiemstra, 2000; Castaño, 2002), but values as low as $0.5^{\circ} \mathrm{C} 100 \mathrm{~m}^{-1}$ have been observed (Bacuilima et al., 1999). Air humidity not only decreases the lapse rate, but also lowers the daily temperature variation. In seasons with high cloudiness, the total solar radiation at ground level is low during the day, whereas high relative humidity at night greatly reduces the coldness due to longwave outgoing radiation from the ground and vegetation. An opposite effect occurs during dry days.

Contrary to the temperature, precipitation in the páramo is highly variable, ranging from $700 \mathrm{~mm}$ up to $3000 \mathrm{~mm}$ (Luteyn, 1992), with some extremes in limited areas, up to $6000 \mathrm{~mm}$ (Rangel, 2000). Rainfall variability at a small scale is mainly determined by variations in wind direction and wind speed, which are controlled by the steep slopes and the accidented topography. At a larger scale, the precipitation pattern is influenced by both the Pacific and the Amazon basin. The eastern slopes are dominated by perennially wet easterly trade winds originating over the tropical Atlantic and Amazon basin. In the northernmost Andes of Venezuela, northern Colombia and Costa Rica, the northeast trade winds cause a marked dry season. The western slopes of Colombia and Northern Ecuador are influenced by an intertropical convergence zone (ITCZ) over the eastern Pacific (Vuille et al., 2000). The ITCZ is responsible for a continuous moisture in the form of rain, clouds and fog, as a result of the orographic uplift. Finally, the páramos on the western slopes of south Ecuador and north Peru are influenced by dry and cool airmasses from the Humboldt Current, and are therefore 
much dryer, except during El Niño (Sarmiento, 1986; Luteyn, 1999). The inter-Andean valleys between the western and the eastern mountain range undergo a varying influence from oceanic and continental airmasses, resulting in a bimodal seasonal distribution. These complex interactions, combined with the irregular topography and the large differences in slope, exposure and elevation, result at local scale in strongly varying weather patterns.

An altitudinal effect is superimposed on the regional precipitation mechanisms. On the windward eastern slopes descending towards the Amazon basin, the highest rainfall is found between 400 and $800 \mathrm{~m}$ (Rossenaar and Hofstede, 1992), due to the orographic effect, gradually diminishing with increasing altitude. On the west oriented slopes highest precipitation is found between 2000 and $2500 \mathrm{~m}$ or even higher upslope. The inner Andean slopes are heavily influenced by rainshadow effects, for rains coming from both the Amazon basin and the Pacific lowlands. In some páramos, condensation belts exist at certain altitudes. These belts are wetter, and have a lower amplitude of temperature variation than adjacent areas (Cleef, 1981).

\section{The soils}

The most common soils in the páramo are Andisols, Entisols, Inceptisols and Histosols in the Soil Taxonomy (Soil Survey Staff, 2003) classification, or Andosols, Regosols, Umbrisols and Histosols in FAO's World Reference Base for Soil Resources (FAO/ISRIC/ISSS, 1998). Most páramo soils are volcanic in origin. They form a uniform blanket covering the tertiary bedrock of the Andean cordilleras. Depending on the location, soil thickness ranges from a few $\mathrm{cm}$ to several meters. Despite the complex geology and topography, the soils in the páramo are quite homogeneous.

Two main factors determine the soil type and properties: (1) the climate, and (2) the existence of a homogeneous layer of volcanic ashes from quaternary volcanic eruptions (Sauer, 1957; Colmet-Daage et al., 1967; Barberi et al., 1988; Winckell et al., 1991). The cold and wet climate, and the low atmospheric pressure favour organic matter accumulation in the soil. This accumulation is further enhanced by the formation of organometallic complexes strongly resisting microbial breakdown. Al and Fe for these complexes is supplied by the breakdown of volcanic ashes and bedrock (Colmet-Daage et al., 1967; Nanzyo et al., 1993). The resulting soils are dark and humic and they have an open and porous structure. In more water saturated areas or regions with less volcanic influence, organic soils
(Histosols) develop (Buytaert, 2004). At steeper locations, soils are very thin and show few horizon development (Cleef, 1981; Rangel, 2000).

\subsection{Water retention}

From a physical perspective, the soils of the páramo have many properties in common with upland peat soils. They contain elevated amounts of organic $\mathrm{C}$, which is typically around $100 \mathrm{~g} \mathrm{~kg}^{-1}$. In wet locations $\left(>900 \mathrm{~mm} \mathrm{yr}^{-1}\right.$ ), organic $\mathrm{C}$ contents of up to more than $40 \%$ are not uncommon (Buytaert et al., 2005c). Locations with more frequent ash deposits are characterised by younger soils with a $\mathrm{C}$ content of about $4-10 \%$ (Zehetner et al., 2003). In dryer regions, organic matter accumulation is slower, and similar $\mathrm{C}$ contents are found. Podwojewski et al. (2002) measured $7 \%$ in the páramo of Chimborazo $\left(<600 \mathrm{~mm} \mathrm{yr}^{-1}\right)$. A negative correlation between the altitude and organic $\mathrm{C}$ content is common (Zehetner et al., 2003). Basic physical properties of páramo soils available in literature are given in Table 1. Strongly related to the high organic $\mathrm{C}$ content, the soils have an open and porous structure and a very high porosity and a large hydraulic conductivity. Dry bulk density ranges from as low as $0.15 \mathrm{~g} \mathrm{~cm}^{-3}$ in wet conditions and weathered soils to about $0.9 \mathrm{~g} \mathrm{~cm}^{-3}$ in younger soils in dryer regions (Buytaert et al., 2005c). When the soils are saturated, water content may exceed $4 \mathrm{~g}$ $\mathrm{g}^{-3}$, decreasing to $0.1-2 \mathrm{~g} \mathrm{~g}^{-3}$ at $1500 \mathrm{kPa}$ suction (Table 1).

This extremely high water retention of Andosols has been described by various authors (Rousseaux and Warkentin, 1976; Shoji and Fujiwara, 1984; Nanzyo et al., 1993) and is mostly attributed to the presence of amorphous clay minerals such as allophane and imogolite. Yet, many páramo soils, in particular highly weathered soils in wet regions, are devoid in short range order minerals. In these soils, $\mathrm{Al}$ and $\mathrm{Fe}$ released by volcanic ash breakdown is completely bound to organic matter forming organometallic complexes (Poulenard, 2000; Buytaert, 2004). Though, organic $\mathrm{C}$ accumulation gives rise to a hydrological behaviour that is very similar to allophanic soils (Buytaert et al., 2005a). In particular, $1500 \mathrm{kPa}$ water content and the amount of micropores, is highly affected by the amount of organic $\mathrm{C}$. As a result, organic colloids are very important in microporosity development. The increase in volume of micropores $(>2 \mu \mathrm{m})$ due to organic $\mathrm{C}$ ranges from $4.1 \mathrm{~m} \mathrm{l} \mathrm{g}^{-1}$ (Buytaert et al., 2005a) to $7.5 \mathrm{ml} \mathrm{g}^{-1}$. This value is much higher than what is commonly found in most soil types $\left(0-3 \mathrm{ml} \mathrm{g}^{-1}\right.$, Brady and Weil, 1999; Poulenard et al., 2001). 
Table 1

The value range of hydrophysical soil properties in the upper horizons ( $\mathrm{H}$ and/or $\mathrm{A})$ in páramo soils described in literature. The literature references are: 1. Buytaert et al. (2005c); 2. Buytaert (2004); 3. Buytaert et al. (2002), 4. Podwojewski et al. (2002), 5. Poulenard et al. (2003); 6. Poulenard et al. (2001); 7. Zehetner et al. (2003); 8. Pérez (1984, 1991, 1992); 9. Rangel (2000). CO = Colombia; EC = Ecuador; VE = Venezuela

\begin{tabular}{|c|c|c|c|c|c|c|c|}
\hline \multirow[t]{2}{*}{ Source } & \multirow[t]{2}{*}{ Location } & \multirow{2}{*}{$\frac{\text { Altitude }}{\text { (m alt.) }}$} & \multirow{2}{*}{$\frac{\text { Precipitation }}{{\mathrm{mm} \mathrm{yr}^{-1}}^{-1}}$} & \multirow{2}{*}{$\frac{\text { Bulk density }}{\mathrm{g} \mathrm{cm}^{-3}}$} & \multirow{2}{*}{$\frac{\text { Organic C }}{\%}$} & \multirow{2}{*}{$\frac{33 \mathrm{kPa}^{*}}{\mathrm{~g} \mathrm{~g}^{-1}}$} & \multirow{2}{*}{$\frac{1500 \mathrm{kPa}^{*}}{\mathrm{~g} \mathrm{~g}^{-1}}$} \\
\hline & & & & & & & \\
\hline 1 & Rio Paute basin, EC & 3600 & $800-1300$ & $0.23-0.95$ & $14-44$ & - & $0.29-2.26$ \\
\hline 2 & Machangara, EC & 3700 & 1100 & $0.13-0.27$ & $18-34$ & - & $1.31-2.39$ \\
\hline 2 & Ningar, EC & 3400 & 950 & $0.15-0.93$ & $4-27$ & - & $0.26-1.78$ \\
\hline 3 & Jima, Cuenca, EC & 3100 & 1000 & $0.58-0.67$ & $2-14$ & - & $0.36-0.78$ \\
\hline 4 & Chimborazo, EC, humid & 3500 & $>900$ & 0.68 & $7-10$ & $0.7-0.8$ & - \\
\hline 4 & Chimborazo, EC, dry & 3500 & $<600$ & $0.74-0.93$ & $5-7$ & 0.3 & - \\
\hline 4 & Chimborazo, EC, pantanal & 3500 & $>900$ & $0.11-0.36$ & $12-42$ & $1.5-4.0$ & - \\
\hline 5 & Azogues, EC & 3250 & 1860 & $0.42-0.90$ & $4-18$ & - & $1.30-1.42$ \\
\hline 5 & Cuenca, EC & 3700 & 1270 & $0.35-0.40$ & $19-23$ & - & $1.15-2.20$ \\
\hline 6 & Pichincha, EC & 4000 & $1500-2000$ & $0.7-0.9$ & $3-13$ & - & $0.27-0.52$ \\
\hline 6 & El Angel, EC & 3600 & 1150 & $0.4-0.6$ & $9-21$ & - & $0.59-0.97$ \\
\hline 7 & Cotacachi, EC & $3400-4050$ & 1500 & & $4-10$ & - & - \\
\hline 8 & Piedras Blancas, VE & 4400 & 800 & $0.59-1.07$ & $1-5$ & $0.09-0.50$ & - \\
\hline 9 & Sierra Nevada, CO & 3920 & - & 1.40 & 1 & 0.12 & 0.06 \\
\hline 9 & Sierra Nevada, CO & 3460 & - & 0.91 & 5 & 0.43 & 0.23 \\
\hline 9 & Cordillera Oriental, CO & 3650 & - & 0.72 & 9 & 0.73 & 0.52 \\
\hline 9 & Cordillera Oriental, CO & 3260 & - & 0.65 & 21 & 1.25 & 0.43 \\
\hline 9 & Cordillera Central, CO & 3090 & - & 0.96 & 7 & 0.45 & 0.32 \\
\hline 9 & Cordillera Central, CO & 3520 & - & 0.71 & 18 & 0.64 & 0.48 \\
\hline
\end{tabular}

*Gravimetric water content at field capacity $(33 \mathrm{kPa})$ and wilting point $(1500 \mathrm{kPa})$, respectively.

\subsection{Hydraulic conductivity}

Information about the hydraulic conductivity and infiltration capacity of páramo soils is scarce. It is generally accepted that, in view of the low precipitation intensity, surface runoff in the natural paramo is limited to nonexistent (Sarmiento, 2000; Harden, 2001). Reported values for volcanic ash derived páramo soils are around 50-60 $\mathrm{mm} \mathrm{h}^{-1}$ (Poulenard et al., 2001) and 10-20 mm $\mathrm{h}^{-1}$ (Buytaert et al., 2005a). Applying several in situ and laboratory techniques (constant head permeameter, inverted augerhole method and tension infiltrometer) for the determination of the soil hydraulic conductivity gives similar results in both average value and range. Generally, the variability in hydraulic conductivity is small, to such an extent that the representative elementary volume of páramo soils may be as low as $100 \mathrm{~cm}^{3}$ (Buytaert et al., 2005a). The conclusion of a low spatial variability and a high hydraulic conductivity seem to contradict the importance of preferential flow paths and the predominance of micropores as observed by Podwojewski et al. (2002). Further investigation of the structure of páramo soils and the relation of porosity with hydraulic conductivity is therefore recommended. Finally, the mean hydraulic conductivity sharply drops when only low suctions are applied. In tensio-infiltrometer field experiments, Buytaert et al. (2005a) saw a reduction of the hydraulic conductivity from $5.3 \mathrm{~mm} \mathrm{~h}^{-1}$ at $-3 \mathrm{~cm}$ suction to $0.52 \mathrm{~mm} \mathrm{~h}^{-1}$ at $-15 \mathrm{~cm}$.

\section{The hydrological cycle}

The páramo is well known for its very large water surplus and sustained base flow, feeding the rivers descending to both the coastal regions and the Amazon basin. The extreme water regulating capacity of the páramo is frequently described (e.g., Luteyn, 1992; Hofstede, 1995c; Sarmiento, 2000; Mena and Medina, 2001; Podwojewski et al., 2002; Poulenard et al., 2003). In the next section, some experiments that quantify the water production and regulation capacity of the páramo are reviewed, and related to the characteristics of the ecosystem.

\subsection{Water production}

The average water production of the Colombian páramo is estimated at about $1400 \mathrm{~mm}$, equaling $66.5 \mathrm{~km}^{3} \mathrm{yr}^{-1}$ (Hincapié et al., 2002). In Ecuador, no overall estimations are known, and case studies are also scarce. Buytaert et al. (2004) analysed runoff series of small páramo catchments. Their water production is between 600 and $1000 \mathrm{~mm} \mathrm{yr}^{-1}$, which is about $2 / 3$ of the annual rainfall (Fig. 5).

The high water production is primarily due to elevated precipitation. As described above, precipitation 


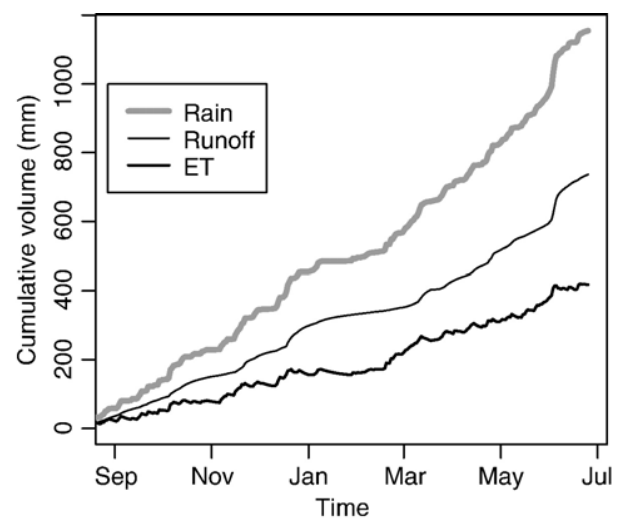

Fig. 5. Cumulative water balance of a typical south Ecuadorian páramo catchment, after Buytaert et al. (2004). Discharge and rainfall were measured with a V-notch and tipping bucket rain gauges, while evapotranspiration (ET) is calculated as the cumulative difference between daily rainfall and daily discharge.

in the páramo ranges from 700 to $3000 \mathrm{~mm}$. Yet the real water input in the hydrological system is probably significantly higher. As can be seen in Fig. 6, rainfall events in the páramo are typically of high frequency and low intensity. In combination with strong winds and a very accidented topography (rain shading) this results in a high spatial rainfall variability and large errors in precipitation registration (Buytaert, 2004). Additionally, precipitation due to fog and dew and interception by vegetation, may add an unknown quantity of water to the hydrological system, especially where patches of arbustive species such as Polylepis sp. are present. This mechanism is similar to occult precipitation in montane cloud forest, where it typically adds 5 to $20 \%$ of ordinary rainfall (Bruijnzeel and Proctor, 1995; Ataroff and Rada, 2000). In an unpublished study in Carchi, Veneklaas (personal communication, 2005) monitored fog interception in the Ecuadorian páramo region by means of cylinders of 1-mm mesh steel gauze. The total yield was about $20 \mathrm{~mm} \mathrm{month}^{-1}$, or roughly $20 \%$ of the total rainfall during the same period. However, extrapolating these results to natural conditions is not evident. No standard method for fog interception exists, and real interception depends on tree height, canopy structure and size, biomass, orientation, physical characteristics of leaves and epiphytes (Gonzalez, 2000). These characteristics vary considerably, and for most vegetation types, they are hardly known.

Low natural water consumption is a second reason for the sustained water production of the páramo. The tussock grasses may have a large leaf area index, but the green leaves are sheltered from radiation and dry air by accumulated dead leaves. The herbaceous vegetation is characterized by xerophytic species with low evaporation characteristics. As a result, actual evapotranspiration is low. Efforts to quantify the actual evapotranspiration of the grass páramo are scarce. Literature values range from $0.8 \mathrm{~mm}$ day $^{-1}$ to about $1.5 \mathrm{~mm} \mathrm{day}^{-1}$ (Hofstede et al., 1995; Buytaert, 2004), but these values are prone to uncertainty. First, most are based on Penman-Monteith reference evapotranspiration estimates, but the validity of this method for low latitude and high altitude regions is questionable (Garcia et al., 2004). Secondly, the particular transpiration properties of the páramo vegetation are poorly studied and further complicate the calculation of the actual evapotranspiration. For the arbustive Polylepis vegetation, they are completely unknown.

From the previous section we may conclude that the natural páramo vegetation (both grasslands and arbustive species) play an important role in the water cycle. This role extends beyond water consumption, as observations suggest that interception and microclimate regulation may be important as well. The stringent lack of data about the hydrological features of páramo vegetation is therefore an important topic for future research. It is particularly worth noting the role of epiphytes in water capture, storage and release, because although they occur abundantly in Polylepis forests, their hydrological behaviour is poorly understood (Veneklaas et al., 1990; Gonzalez, 2000).

\subsection{Water regulation}

Few efforts to quantify the overall hydrological regulation capacity of the páramo exist. Buytaert et al. (2004) analysed discharge volumes from small Ecuadorian páramo catchments (about $2 \mathrm{~km}^{2}$ ) and found a peak flow/base flow ratio of 5.0 for a natural catchment and 11.9 for a cultivated and drained catchment. Despite of the relative scarceness of data, it is generally acknowledged

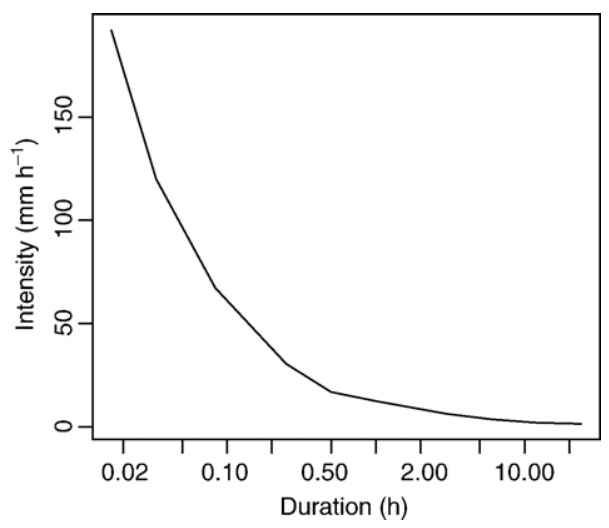

Fig. 6. Maximum intensity-duration curve of the Huagrahuma experimental catchment (Machangara, Ecuador) for a 3 year period. 
that páramo rivers provide a sustained base flow throughout the year (Luteyn, 1992; Buytaert et al., 2004).

As is explained in the previous section, the role of the páramo vegetation in the hydrological regulation is unclear. The major role of the tussock grasses and dwarf shrubs is soil protection (Hofstede, 1995c). Evaporation from bare soil surfaces would be very high, because of the dark soil colour and the high radiation at this altitude and latitude. Furthermore, drying of the soil may cause irreversible structure degradation and loss of water retention capacity. The water regulating capacity of the Polylepis forests is probably higher, because of the higher biomass and the thick litter layer.

As explained in previous sections, the soils are given most credit for the high water regulation capacity (e.g., Luteyn, 1992; Mena and Medina, 2001; Poulenard et al., 2003), because of the light and porous soil structure and the extraordinary water retention capacity (Table 1 ). The high water retention at $1500 \mathrm{kPa}$ indicates a predominance of micropores in the soil and the presence of a large reservoir of inactive water, which may not contribute significantly to the hydrological cycle in the páramo (Buytaert et al., 2005a). Nevertheless, the water storage capacity above $1500 \mathrm{kPa}$ suction is regularly higher than $0.4 \mathrm{~g} \mathrm{~cm}^{-3}$ (Buytaert, 2004).

How much of this storage reservoir is active in the hydrological cycle is unknown. In wet páramos with low seasonal climate variability, the variation in actual soil water content is very small, and may be less than $25 \mathrm{~mm}$ (Fig. 7). In this environment, the hydrological significance of the soils is probably secondary to that of climate and topography (Sarmiento, 2000). In páramos with a stronger seasonal variability, the water regulation capacity of the soils is likely to be more significant, but no detailed studies are known.

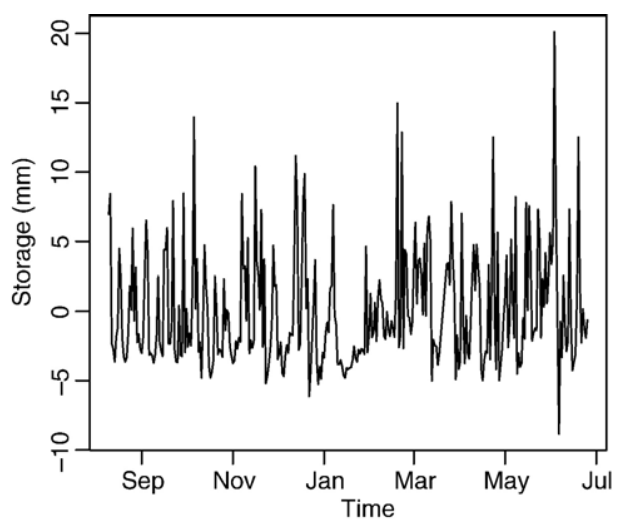

Fig. 7. Storage variation in the natural Huagrahuma catchment based on a water balance model, after Buytaert et al. (2005b).
While not a "regulation" as such, the low seasonality in the páramo climate and the equal distribution of rainfall over the year (Fig. 4) may indeed be a major source of the sustained base flow in rivers coming from the páramo. While the total amount of rainfall is not particularly high in most páramos, the region is known as very cold and wet, because it is almost continuously covered with fog and drizzle. In the south Ecuadorian páramo, for instance, less than one day in four it does not rain (Buytaert, 2004). But, daily rainfall data from the páramo region and detailed analysis of the temporal variability and the autocorrelation are almost nonexistent.

Finally, the topography itself is responsible for an elevated regulation capacity. After the Andean uplift from the Miocene to the Pleistocene, the páramo topography was further shaped by glacial activity. Remnants are still abundantly visible in the structure of valleys and give the páramo its typical accidented topography, ranging from rough and steep valleys to almost flat plains (Kehrer and der Kaaden, 1979; Hungerbühler et al., 2002). The irregular landscape is home to abundant concavities and local depressions where bogs and lakes have developed. For instance, the 28,544 ha national park El Cajas at about $30 \mathrm{~km}$ west of Cuenca, hosts 235 permanent lakes, giving a density of 0.8 lakes $\mathrm{km}^{-2}$. These lakes may add to the water storage and buffering capacity of the ecosystem. Although the concepts to quantify the regulation capacity of lakes are well known, no studies are known for the páramo. This is most probably due to the lack of detailed topographical data for most páramos. Many smaller lakes and local depressions are disconnected from the drainage network. They collect overland flow from slopes and allow for infiltration and recharge of deep ground water storage reservoirs (Price and Waddington, 2000).

\section{Páramo water use}

Given the high water production and regulation capacity, it comes as no surprise that water from the páramo is intensively used. Because of the difficulties in extracting groundwater in the Andean highlands, surface water from the páramo is used for consumption, irrigation and hydropower generation. Together with organic $\mathrm{C}$ storage, it is the most important environmental service provided by the páramo. It is estimated that the high Andean wetland ecosystems, of which the páramos are by far the most important, provide environmental services to more than 100 million people (IUCN, 2002). The importance of the water supply function is described in detail in the following sections. 


\subsection{Domestic water use}

It is impossible to quantify the total human consumption of páramo water. Many local communities near the páramo use their own water supply system. In lower regions, the contribution of the páramo to the total discharge of rivers and the dampening of base flow variability cannot be quantified due to the lack of hydrological and meteorological data records of an acceptable time span. Only for larger cities, the water use is well documented.

Many Andean cities almost completely depend on páramo water, especially since other natural areas with a high potential water supply, like Andean forests, have disappeared. For example, Bogotá (Colombia) almost exclusively uses water from the páramo. The city has a population of about 7 million and an average fresh water demand of $27 \mathrm{~m}^{3} \mathrm{~s}^{-1}$. Water is taken from two major reservoirs: Chingaza and La Regadera, supplied by respectively the páramos of Chingaza and Sumapaz (UAESPNN, 2000). Quito (Ecuador) uses surface water for $85 \%$ of its supply $\left(7.4 \mathrm{~m}^{3} \mathrm{~s}^{-1}\right)$, exclusively from the páramo. The major water suppliers are the Papallacta intake (3900 m altitude) on the Cunuyacta river in the Cayambe-Coca reserve, the Micacocha captation (3900 m altitude) on the slopes of the Antisana Volcano and the Rio Pita at $3200 \mathrm{~m}$, coming from Cotopaxi and Sincholagua volcanoes. Cuenca (Ecuador) uses only surface water as a water supply for its 420,000 habitants. Three captations are used: Tomebamba (and its tributary Mazan), Yanuncay, and Machangara. The water captations are located at about $3000 \mathrm{~m}$, on the lower limit of the páramo. Machangara river descends from the equally named páramo region, a watershed of about $204 \mathrm{~km}^{2}$. The Tomebamba and Yanuncay rivers descend from the páramo of El Cajas National Park.

\subsection{Irrigation}

Irrigation in the Andean highlands is a long-standing practice. Already in precolumbian times, the Cañari culture, among others, was very active in the construction of large irrigation schemes. The Incas improved these infrastructures, applying knowledge of other conquered cultures in present Peru and Bolivia. During the Spanish colonial time, irrigation systems were constructed and managed on a private basis by the landlords of large haciendas. From the 1950s onwards, and especially during the 70s, many irrigation projects were constructed by the government, funded by the booming oil exploitation and export.

In 1997, irrigated land covered $8630 \mathrm{~km}^{2}$ of Ecuador, representing about $30 \%$ of the total agricultural area. Irrigation water is almost exclusively provided by surface resources, supplying more than $98 \%$ of the total irrigation needs. In Colombia, about $9000 \mathrm{~km}^{2}$ of farming land is currently irrigated, consuming $37 \%$ of the country's water supply. However, irrigation potential in both countries is estimated at resp. $12,000 \mathrm{~km}^{2}$ (Ecuador) and $66,000 \mathrm{~km}^{2}$ (Colombia), largely exceeding the currently irrigated area (FAO, 2000). Future water demand is therefore expected to increase strongly.

Below $3000 \mathrm{~m}$ altitude, the major meteorological constraint for crop production is rainfall, as temperature is sufficiently high throughout the year. A typical climatic pattern is given in Fig. 8, in which variation of reference evapotranspiration and precipitation in the meteorological station of Cañar are given. As can be observed in Fig. 8, irrigation requirements are quite erratic. In a wet year, considering rainfall with $20 \%$ probability of occurrence, irrigation is only needed from June to January, while during a dry year, considering rainfall with a probability of occurrence of $80 \%$, irrigation is needed throughout the year. In such a year, rainfed agriculture, which is assumed to be possible when rainfall is higher than half the reference evapotranspiration, is not possible. In general, it can be stated that in most places, rainfall contributes sufficiently to crop water requirements throughout the year and that irrigation is complementary in terms of necessary water volume. Yet, it is a must for food production security in terms of rainfall variability (De Bièvre, 2002).

As an example, Dercon et al. (1998) summarize the agro-ecological zones in the Austro Ecuatoriano (Ecuador)

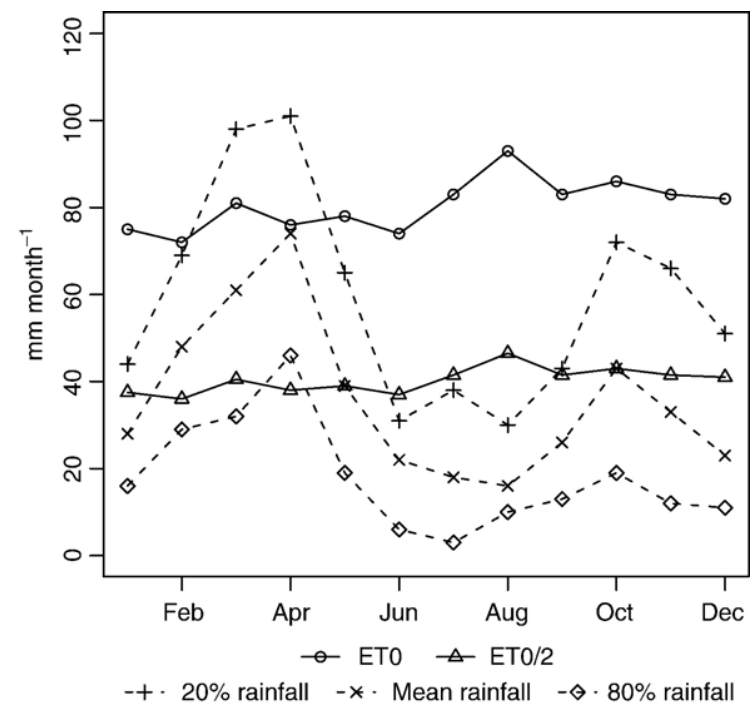

Fig. 8. Major characteristics of the climate in the Cañar region (3000 m). For monthly rainfall, the mean and the $20 \%$ and $80 \%$ exceedance probability limits are given. As a rule of thumb, irrigation is required when rainfall is lower than ET0/2. For dry years, this may be throughout the entire year. 
between 600 and $3000 \mathrm{~m}$ altitude. More than $75 \%$ of the total area has a growing season of maximally 10 months and thus benefits from irrigation. In $25 \%$ of the area, the natural growing season is 6 months or less. In these areas irrigation is socially and economically indispensable.

For the irrigation of both the large scale banana plantations in the coastal plains and the small holdings that characterise sierra agriculture (minifundio), water from the páramo highlands is used. Irrigation demand depends strongly on the location, climate and crops. Water requirements for a typical irrigation project in the Cañar region is about $1.5 \mathrm{~mm}$ day $^{-1}$ (Patacocha irrigation scheme, De Bièvre, 2002). Because of the inefficiency of most irrigation systems, however, the typical water demand is much higher.

\subsection{Hydropower}

The Andean topography provides good opportunities for hydropower production. The constant and reliable base flow in the Andean rivers guarantees a constant and efficient power generation. The rio Paute catchment is home to one of the largest hydropower plants in the Andean region. The Amaluza reservoir is located at $1994 \mathrm{~m}$ altitude and stores about $120 \cdot 10^{6} \mathrm{~m}^{3}$. The power plant's capacity is $1075 \mathrm{MW}$ and provides 55 to $60 \%$ of Ecuador's electricity (Southgate and Macke, 1989). Estimates say that, on average, between 25 and $40 \%$ of the water arriving in the Amaluza reservoir originates from the páramos in the Western and Central Cordillera. In dry periods, however, it can reach $100 \%$. Two more power plants (Mazar and Sopladora) are planned to be constructed on the same river and would generate another $1000 \mathrm{MW}$.

Currently, the focus has shifted towards small, multifunctional hydropower plants, the reason being that remediation costs per generated unit of power are lower for smaller reservoirs. In addition, many of these small reservoirs are used as storage reservoirs in irrigation schemes or for the production of drinking water. The Saucay and Saymirin power plants in the Ecuadorian rio Paute basin are a typical example. The system consists of two reservoirs, El Labrado and Chanlud, with a capacity of respectively $6.2 \cdot 10^{6}$ and $17 \cdot 10^{6} \mathrm{~m}^{3}$. These reservoirs supply water to two powerplants in series, generating together 38.4 MW. In addition, they are also major water suppliers for the city of Cuenca (see Section 6.1).

\section{Human interference}

It may be clear from previous sections that the páramo is an important element in the moderation of the hydrology and that its conservation is a priority for the socio-economic development of the Andean highlands. Human activities might put serious constraints on this conservation.

A major problem in assessing human impact on ecosystems is the availability of data for a pristine ecosystem as a reference. For the páramo, this is nearly impossible as human presence goes back to precolumbian times (Schjellerup, 1992). Grazing and burning are common practice for ages and may have favoured the current vegetation of tussock grasses over original natural forests (Verweij and Budde, 1992; Cavelier et al., 1998; Sarmiento, 2002). Fires have occurred in the páramo during the whole Holocene but it is unknown to which extent they are anthropogenic. In general, palynological data from different páramos are often contradictory, and because of the low spatial resolution of such data the exact position of the treeline cannot be derived with certainty (Wille et al., 2002). Palynological data from the páramo of south Ecuador show that the treeline has been at a slightly higher altitude in the late Holocene than at present, though never as high as the highest forest patches found today, which probably rely on locally favourable circumstances. The lowering is attributed to human impacts, which are recorded in the pollen signal from about $5000{ }^{14} \mathrm{C}$ yr BP (Hansen et al., 2003).

Historical activities have always remained rather local and little intensive. As such, they interfered little with the hydrology (Abadín et al., 2002). But, the intensity and the nature of human activities in the páramo have increased drastically. Infrastructures are built at a fast pace, livestock grazing is intensified and grasslands are converted to agricultural fields that are drained and cultivated intensively. This presence has a strong impact on the water cycle. Changes in or removal of the vegetation affect evapotranspiration and may result in changing soil properties. Drainage results in dryer soils and therefore reduces evaporation, but may increase runoff and erosion. After drainage, organic soils may initially moderate flood flows in dry conditions because of increased soil storage. As time passes, peat compaction and decomposition generally cause the runoff to increase (Charman, 2002; Holden and Burt, 2002, 2003b). Overgrazing, trampling and burning also encourage accelerated runoff and erosion. Such problems can become critical when these regions are used as a water supply. This is for instance the case in the rio Paute basin, south Ecuador, where elevated sediment loads in rivers used for urban water supply and hydro power, is attributed to humanly induced erosion (cf. Section 6.3).

The velocity of land use changes has been quantified at several locations. Van der Hammen et al. (2002) 
quantified the land use changes in the páramo of Laguna Verde in Cundinamarca, Colombia. From 1970 to 1990, cultivation increased with $106 \%$, grasslands with $164 \%$. High altitudinal forests decreased with $32 \%$. For the whole country, the increase in cultivated area in the páramo was estimated at $24.9 \%$ (Hincapié et al., 2002).

Land use changes in adjacent regions may also affect páramo climate. Cloud formation in downslope montane cloud forests is assumed to sustain air humidity in upper mountain regions (Bruijnzeel and Proctor, 1995; Foster, 2001). Massive deforestation of the Andean slopes occurred during the last century and as a result, it may have altered the páramo climate.

Finally, on a larger scale, global climate change or disturbance of the ENSO phenomenon affect the local páramo climate and the hydrological cycle. The next sections elaborate on these impacts.

\subsection{Hydrological soil properties}

\subsubsection{Runoff, infiltration and aggregate stability}

Infiltration is a key aspect of water regulation (Calder, 1998). In natural circumstances, infiltration in Andosols is high, and therefore sediment loss is low (Nanzyo et al., 1993). Even then, various authors report on an increase of the hydraulic conductivity and the hydrodynamic dispersion of Andosols when taken into cultivation (e.g., Wada, 1985; Nanzyo et al., 1993; Basile and De Mascellis, 1999; Buytaert et al., 2002). On the other hand, compaction of the soil surface and the development of crusts, inducing faster runoff initiation and less infiltration are also reported (Neall, 1985).

A similar ambiguity is found in literature about the human impact on páramo soils. In the Colombian Andes, Hofstede (1995b) did not observe significant differences in infiltration capacity between burned and grazed plots and natural páramo. Sarmiento (2000) report on similar findings in the Venezuelan páramo. Both in cultivated and natural plots, runoff remains below $2 \%$ of the total rainfall. In fact, more erosion may occur in abandoned land than on cultivated fields, as the infiltration capacity in the latter is kept at a sufficient level because of regular ploughing (Harden, 2001).

On the other hand, Poulenard et al. (2001) studied the effects of burning and grazing in the north Ecuadorian páramo and found significant crust formation, increase in runoff and erosion and reduction in hydraulic conductivity. Erosion rates were 5 to 10 times higher in cultivated plots, and the runoff coefficient increased about 300\%. Podwojewski et al. (2002) report similar problems in the Ecuadorian páramo of Chimborazo, due to intensive sheep grazing.
The main cause of this ambiguity may be attributed to the intensity of the human activities. In natural conditions, the stability of Andosol aggregates is high (Nanzyo et al., 1993) and it is one of the major factors in the development of an open, permeable structure. Strong complexation of organic $\mathrm{C}$ with amorphous forms of $\mathrm{Fe}$ and particularly $\mathrm{Al}$ prevents aggregation of soil particles and the loss of water stability as commonly observed in non-volcanic soils. Therefore, the threshold level for structural breakdown and aggregate stability is generally higher than non-volcanic soils (Tisdall and Oades, 1982; Shepherd et al., 2001).

Studies that quantify the carrying capacity of the páramo soils, however, are scarce. Molinillo and Monasterio (1997) calculate the carrying capacity of the Venezuelan páramo at about 1 animal per 13 ha in the wet season and 1 animal per 24 ha during the dry season. The maximum carrying capacity of the páramo is estimated between 0.1 and 1 animal per ha (Schmidt and Verweij, 1992; Hofstede, 1995a) but these rates are only possible in ideal conditions (flat terrain, good soil cover and non-degraded soils) and when the loss of biodiversity is not considered.

On the other hand, intensive cultivation and other practices such as burning can severely affect soil stability. These practices induce the formation of hydrophobic and stable soil aggregates with high water repellency (Valat et al., 1991; Golchin et al., 1997; Piccolo and Mbagwu, 1999). In Ecuadorian Andosols, the water contact angle of burned soils may increase up to $90^{\circ}$, compared to $50-60^{\circ}$ before burning. The degree of water repellency depends on both the quantity and type of organic matter (Poulenard et al., 2001). However, in most páramos, fires are of low intensity, and probably hardly affect the soil properties (Hofstede, 1995b).

In a few places, e.g. in northern Ecuador, hardened volcanic-ash soils with elevated amounts of $\mathrm{Ca}$ and/or $\mathrm{Si}$ ("cangahua") emerge as a result of tillage erosion. In these places, runoff is extremely high. Some remediation techniques have been proposed, but at present with limited results (de Noni et al., 2000; Podwojewski and Germain, 2005).

\subsubsection{Water retention}

Andosols are prone to irreversible water retention degradation when dried or cultivated. Both allophanic and non-allophanic Andosols are affected, although the water retention mechanism of both soil types is very different.

In allophanic Andosols, air drying provokes a 20-28\% reduction in the surface area of allophane (Basile and De Mascellis, 1999), resulting in a loss of micropores and a decreasing water retention capability. These effects can 
also occur when Andosols are exposed to direct sunlight, for example when taken into cultivation (ClermontDauphin et al., 2004). Buytaert et al. (2002) and Poulenard et al. (2003) showed that an irreversible reduction in water retention also occurs in non-allophanic Andosols. Here, the high organic matter content is responsible for the elevated water retention. Drying these soils induces structural changes and hydrophobicity in the organic matter. The result is an irreversible decrease of the water retention, up to $40 \%$ (Buytaert et al., 2002).

Besides allophane or organic matter destruction, soil structural degradation may occur in Andosols through mechanical stress. In natural circumstances, most Andosols are characterised by a strong and open structure, as a result of micro-aggregation and a high shear strength. However, dehydration, aggregation and an irreversible decrease in porosity have been reported due to compaction and mechanical cultivation, giving rise to a higher erosion susceptibility (Dorel et al., 2000).

Many of these processes have been observed in páramo soils. Buytaert et al. (2002) and Buytaert et al. (2005a) report on an irreversible water retention reduction in Ecuadorian Andosols that are ploughed and taken into cultivation. The observed reductions range between 2 and $26 \%$, depending on the soil type, the type of cultivation and the water retention pressure. (Podwojewski et al., 2002) report a similar reduction in Ecuadorian Andosols intensively grazed by sheep, accompanied by a soil $\mathrm{C}$ reduction of about $40 \%$ and an increase in water repellency. In Colombia, Hofstede et al. (1995) studied the water content in intensively burned and grazed páramo plots. Here, burning and grazing also introduces structural changes because of drying of the soil and a subsequent faster mineralisation of the organic matter. Finally, changes in the water retention and soil organic $\mathrm{C}$ content of soils under pine plantation were reported by Farley et al. (2004). In a comparative study, the upper horizon of soils under 25 years old pine plantations contained resp. 35 and $57 \%$ less organic $C$ than grassland soils. The water retention reduced with as much as $62 \%$.

\subsubsection{Storage capacity and hydrological response}

Cultivation and compression affects primarily the larger pores which are responsible for water retention at the low suction range, and most soils have a very low water retention capacity at $1500 \mathrm{kPa}$ (Warkentin and Maeda, 1980). As a result, the water retention at low suctions decreases more than water retention at high suction, and the total water retention decreases. This process is visualized in Fig. 9. Few studies in the páramo have considered the water retention capacity of the soils at more than one pressure. It is noteworthy that all studies that do so, report a stronger degradation of the water retention at high suction $(1500 \mathrm{kPa})$ than at low suction $(0-100 \mathrm{kPa})$ (Buytaert et al., 2002; Farley et al., 2004; Buytaert et al., 2005a). As a result, the water storage capacity, i.e., the amount of water stored at suctions below $1500 \mathrm{kPa}$, of cultivated soils can be higher than that of natural soils (Fig. 9). This is not uncommon in Andosols (Anonymous, 1964). From a hydrological perspective, water stored at suctions higher than $1500 \mathrm{kPa}$ can be considered as an inactive storage reservoir. Partial decomposition of the organic matter and soil structural degradation releases a part of this fraction, thus increasing the active water storage capacity of these soils.

Yet, the implications of a larger water storage capacity of the soils on the hydrology at catchment scale are not completely clear. Theoretically, a better water regulating
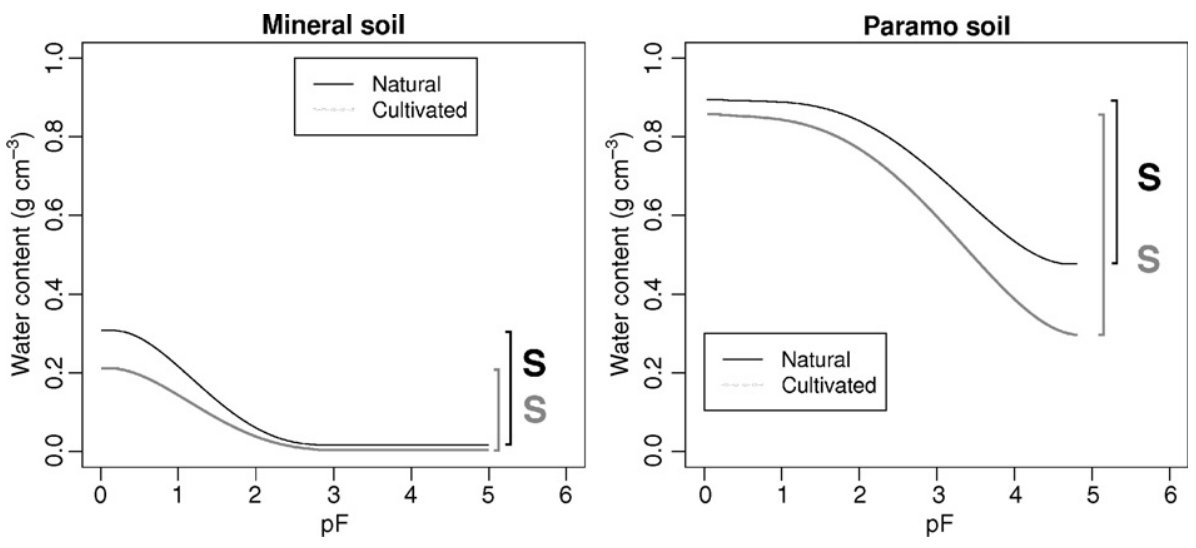

Fig. 9. Schematic representation of the possible impact of cultivation on the water retention curve and the water storage capacity (S). Left: in a "normal" clayey soil, lower suctions are more affected than higher suctions, resulting in a net storage loss. Right: in páramo soils, observations suggest that the high suction range is affected more than the lower suction range, resulting in a net storage increase. 
capacity of these soils would be expected, but this has not been observed in the field. On the contrary, Buytaert et al. (2005a) observed a faster hydrological response despite the higher water storage capacity of the cultivated soils. For comparable storm events higher peak flows were registered, while the base flow was clearly lower in the interfered catchment (Fig. 10). They concluded that the water regulating capacity of a disturbed catchment is up to $40 \%$ lower than a natural grassland catchment, despite a higher saturated hydraulic conductivity, infiltration capacity, and water storage capacity observed in cultivated soils. This may be explained as follows. Given a high natural infiltration capacity and low rain intensity, overland flow is thought to be caused by saturation excess rather than infiltration excess (Hortonian flow). Hence, small alterations in the infiltration capacity do not have a strong effect on the hydrological response. On the other hand, surface roughness and local depressions are important in delaying surface runoff. Removal of the vegetation, disappearance of the organic litter layer and tillage decrease surface roughness (Hofstede et al., 1995). Artificial drainage interconnects local, previously unconnected depressions. These processes accelerate surface runoff, and seem to override the effect of an increased soil water storage.

It has to be noted though that Buytaert et al. (2002), Farley et al. (2004) and Buytaert et al. (2005a) studied recently converted páramos ( $<25$ years). Over time, the stability of the increased water storage capacity is doubtful. Intensive drainage and a higher hydraulic conductivity result in a lower actual water content of the soil. On the long term, an overall moisture decrease of the soil accelerates organic matter decomposition, resulting in a lower organic C content (Farley and Kelly, 2004; Farley et al., 2004). The decomposition of organic matter gives a positive feedback for a further reduction of the water retention capacity, finally resulting in a lower water storage. This process is well studied in peatlands, as it is a major source of $\mathrm{CO}_{2}$ emissions (Price and Waddington, 2000). However, the organometallic complexes in most páramo soils are strongly resistant to breakdown, and decomposition is therefore a slow process. Hence, in soils with recent land use changes, this process is not yet fully stabilized and a further degradation is expected.

\subsection{Impact on the water balance}

In Section 5.1, the water balance of the páramo is discussed. Human interference may strongly alter the water balance, with a major impact on the local water consumption (evapotranspiration, water extraction).

Soil water evaporation in grazed and burned plots is generally higher than in natural vegetation, due to (1) a higher water consumption during regrowth of the vegetation (Pels and Verwey, 1992; Sakalauskas et al., 2001) and (2) the smaller protective vegetation layer. The latter is of particular importance in the páramo, with its large solar radiation (Fig. 3) and dark soils. In the Venezuelan Andes, the daily evapotranspiration of a grazed páramo grassland is about $1.92 \mathrm{~mm}$, as can be calculated from the data published by Sarmiento (2000).

Sarmiento (2000), after investigating the water balance of several cultivated plots in the Venezuelan

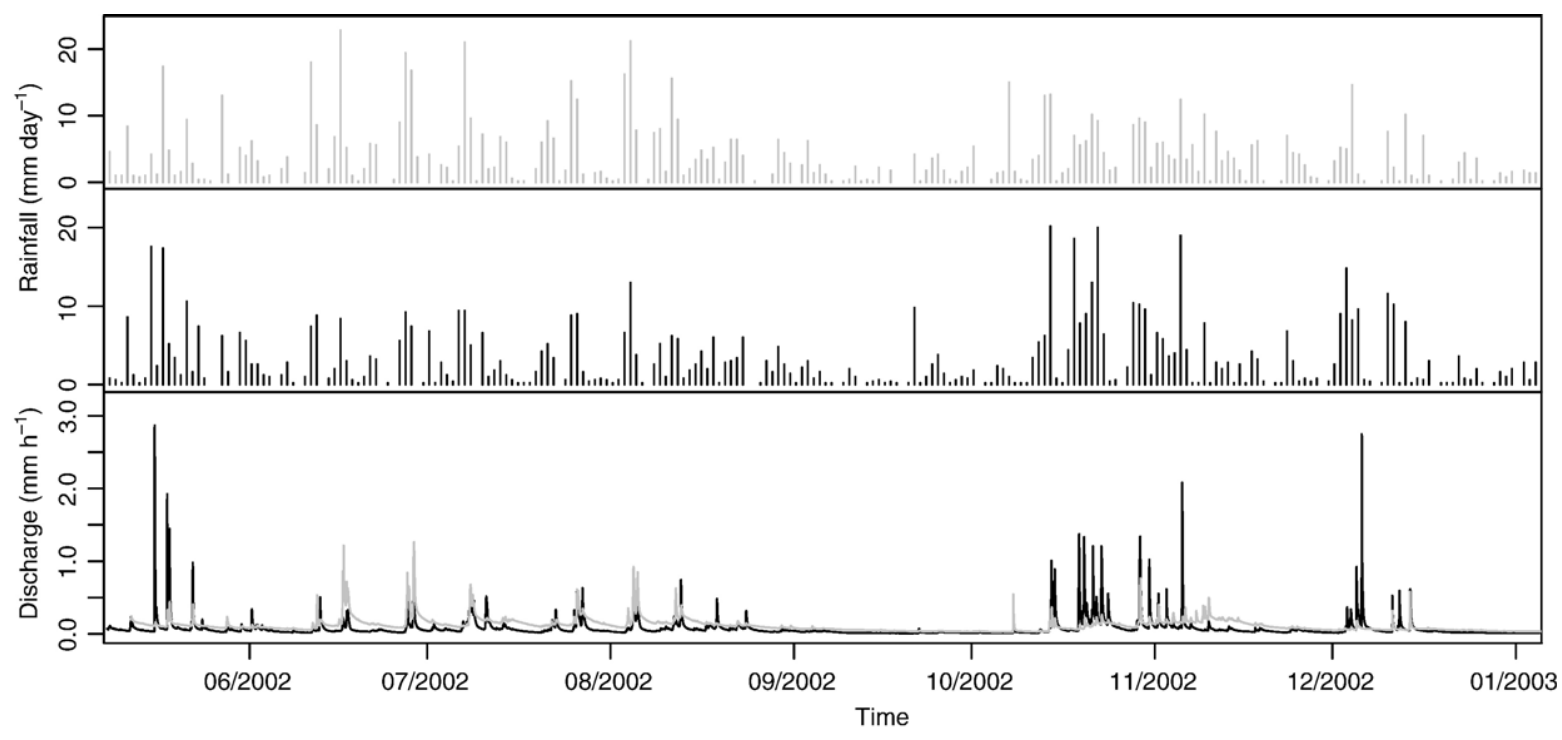

Fig. 10. Rainfall and specific discharge of the intensively cultivated Soroche catchment (black) and the natural grassland catchment Huagrahuma (gray) (Buytaert et al., 2004). 
Andes, concludes that cultivation only to a minor extent affects runoff and drainage. Even in cultivated plots, runoff is very small and soil loss is insignificant. The study also reveals that the water balance of the cultivated plots is dominated by evapotranspiration, forming up to $66 \%$ of the total water output of the system. A major part of this evapotranspiration is related to evaporation during the fallow period and to insufficient plant cover early in the growing season. Similar values were found in the South-Ecuadorian páramo (Buytaert et al., 2005b), and contrast strongly with the evapotranspiration of the grassland, which amounts to about 30\% (Fig. 5).

When human practices such as burning, grazing, cultivation and tree planting involve changes in the vegetation, the impact of these practices on the water balance are more difficult to assess. Burning has a strong impact on the woody vegetation, most notably the local Polylepis species (Keating, 1998). The reduction of forest cover generally increases water yield (Bosch and Hewlett, 1982) but, as discussed Section 5.1, the net water loss of Polylepis forests is completely unknown, so these impacts cannot be quantified. When the natural grass vegetation is replaced by crops, little doubt remains about the increase in evapotranspiration (Sarmiento, 2000). When woody species such as Eucalyptus or Pinus are introduced, water loss may even be substantially higher and base flow may decrease further (Mwendera, 1994; Rowe et al., 1994). PROMAS (2004) describes the only known case study comparing the discharge of a páramo catchment entirely forested with Pinus radiata with the discharge from a natural catchment. The specific discharge of the Pinus catchment was only $30 \%$ of that of the natural catchment. The study area is part of Mazan, providing water for the city of Cuenca, Ecuador. While the currently forested area is rather small, extensive forestation plans with Pinus may be a reason for concern (cf. Section 6.1).

Finally, local water consumption may also affect the local water balance. Mining activities are especially known for the consumption of large quantities of water (Messerli et al., 1997). The water is eventually released back into the hydrological cycle, but strongly polluted.

\subsection{Climate change}

Many studies indicate a strong response of catchment hydrology to an altered climate, with most important changes being runoff quantity and timing. (e.g., Tucker and Slingerland, 1997; Baron et al., 2000; Castaño, 2002; Legesse et al., 2003). Catchments in mountain regions are particularly vulnerable to these changes, as climate change may be stronger at high altitudes than in lower areas (Thompson et al., 2000; Foster, 2001; Messerli et al.,
2004). It is to be expected that, as the climate warms, more water will be pumped into the atmosphere, and the air water vapor content will increase. The lapse rate strongly depends on the air moisture content, and decreases with increasing air moisture content.

\subsubsection{Observations and simulations}

Long time meteorological studies in the páramo are scarce, but some evidence suggests both an increase in temperature and a decrease in precipitation over the last decades. From 1970 to 1990 , the average temperature increased with $1{ }^{\circ} \mathrm{C}$ in the páramo of Cundinamarca, $0.9^{\circ} \mathrm{C}$ in Tolima-Huila and even $1.9^{\circ} \mathrm{C}$ in Boyacá. Over a similar time span, a decrease in monthly precipitation of about $10 \mathrm{~mm}$ was observed in Cundinamarca and Boyacá, and $5 \mathrm{~mm}$ in Tolima-Huila (Castaño, 2002). Timbe (2004) analysed monthly rainfall in the south Ecuadorian rio Paute basin over the last 3 decades. He observed an increased seasonality, with a steady increase of rainfall during the wettest month and a steady decrease during the driest month.

For the northern half of South America, the latest AOGCM simulations predict an increase in temperature between 2 and $3.4{ }^{\circ} \mathrm{C}$, a $3.8 \%$ increase in precipitation during the wet season and a $1.2 \%$ decrease in precipitation during the dry season (Giorgi and Bi, 2005). For the páramo region, however, a larger decrease in precipitation seems more likely (Castaño, 2002). Still, a large uncertainty is involved in these predictions. Not only is the scale at which climate change is currently modelled far below the resolution needed to incorporate the large spatial variability in topography and meteorology which is typically found in the páramo. But also, major processes affecting the páramo climate are currently not included in prediction models. E.g., it is known that deforestation can have regional effects on precipitation patterns (Calder, 1998; Bruijnzeel, 2004). In the páramo, it is thought that the climate is influenced by cloud formation in downslope montane cloud forests, and diminishing rainfall over the last decades has been attributed to widespread deforestation of the Andean slopes (Etter and Villa, 2000; Allan et al., 2002). Future climate change will cause an upward shift of these cloud forests. The resulting further decrease in total area may thus be an important process which further reduces precipitation in the páramo.

Another source of uncertainty is the El Niño Southern Oscillation phenomenon (ENSO). In Colombia and Ecuador, ENSO causes deficit rainfall in mountainous areas. In a warmer climate, ENSO is expected to increase in length and intensity, which would result in a stronger and longer dry period in the páramo (Rossel, 1997; Van der Hammen et al., 2002). 


\subsubsection{Consequences of climate change}

In montane ecosystems, a major consequence of the global increase in temperature is an upward shift of the ecosystem boundaries, which obviously reduces the total area of the upper ecosystems (IDEAM, 2001). Gutiérrez (2002) estimated the future area reduction of the Colombian páramo. She divided Colombia into 28 Holdridge life zones and 33 transition zones, and modelled the future changes in the geographical distribution of these zones, based on the results of the 2XCO2 IPCC scenarios and observed temperature lapse rates. An upward shift of about $450 \mathrm{~m}$ is expected, which is more or less in accordance with the upward shift predicted by Still et al. (1999) for montane cloud forests. Table 2 shows the resulting area reduction for the páramo and the permanent snow areas. For Ecuador, no such studies exist, but the area reduction may be less dramatic, because of the larger extension and the higher average altitude of the Andes.

The consequences of an upward shift of ecosystem boundaries for the hydrology are ambiguous, and depend strongly on the vegetation that replaces the original páramo. The natural vegetation below the páramo belt is mostly tropical montane cloud forests (Foster, 2001). The hydrological production of tropical montane cloud forests is a subject of debate but generally, it is considered to be quite high, because of cloud interception, horizontal precipitation and low consumption (Bruijnzeel and Proctor, 1995). Yet, it is difficult to make a direct comparison between runoff of cloud forests and páramo as it may vary considerably according to local climatic and topographic conditions. Nevertheless, it is much more probable that the agricultural border shifts upwards and that páramo is replaced by cultivated land. As is shown in previous sections, both agriculture and forest plantations have a tremendous impact on the water production and regulation of páramo soils. In both conditions, it is rather straightforward to simulate the hydrological impact of an upward shift of the ecotones, including soil properties, on a certain catchment. Boundary conditions such as climate and soil parent material are not likely to differ very much over an altitude of $450 \mathrm{~m}$, which makes hydrological extrapolation less complicated.

\section{Table 2}

Estimated area reduction for the Colombian upper mountain ecosystems resulting from an upward shift of the ecosystem boundaries of $450 \mathrm{~m}$ (Gutiérrez, 2002)

\begin{tabular}{ll}
\hline Subpáramo & $-47 \%$ \\
Páramo & $-75 \%$ \\
Superpáramo & $-85 \%$ \\
Ice/glaciers & $-95 \%$ \\
\hline
\end{tabular}

As the upward shift of ecotones compensates for the temperature increase, other major climatic changes in the páramo itself are an increased seasonality, and possibly a reduction in precipitation. Of course, these changes have a direct impact on discharge quantity and timing. The total discharge is expected to be smaller, and, depending on the hydrological buffering of páramo catchments, disturbance of streamflow is to be expected. Smaller streams may eventually become intermittent instead of perennial.

Additionally, a dryer climate and an increased seasonality may affect soil hydraulic properties. As is shown in previous sections, the cool and consistently humid conditions contribute to the slow rate of organic matter decomposition. A shift towards a more pronounced dry season may therefore invoke acceleration of organic matter decomposition (Price and Waddington, 2000; Waddington and Roulet, 2000), shrinking (Poulenard et al., 2002) and development of hydrophobicity (Poulenard et al., 2004). Given the strong relation between organic $\mathrm{C}$ content, soil porosity and water retention, these processes may seriously impair the water regulating capacity of páramo soils. Finally, the development of hydrophobicity increases the risk of soil erosion, particularly when combined with removal of the vegetation, e.g., for agricultural purposes. Finally, the decomposition of soil organic matter in the páramo region may be an important source of atmospheric $\mathrm{CO}_{2}$.

While they are not considered as being a part of the páramo, the impact of climate change on glaciers and permanent snow areas affects the páramo, as they are located directly upstream. Reductions in snow cover are widespread (Byers, 2000). Since 1850, the total area covered by permanent snow reduced from 348 to $63 \mathrm{~km}^{2}$ in Colombia. During the last decades, a yearly loss of 0.64 to $1.65 \%$ has been observed, which means that the snow cover of the Colombian Andes will virtually disappear (Table 2). In Ecuador, the only quantitatively studied glacier is Antisana, which recedes at a high pace. During the last decades, the mass balance deficit has varied between 6000 and $1500 \mathrm{~mm} \mathrm{yr}^{-1}$ (Sémiond et al., 1998; Francou et al., 2000). The yearly mass deficit is strongly related to ENSO, enhancing recession because of the negative impact on precipitation. Increased $\mathrm{El}$ Niño events will therefore accelerate recession.

It is not very clear how the disappearance of the snow cover above the páramos will affect their hydrology. Even now, the production of glacier runoff is minimal and only locally significant. It is likely that communities in the dry páramo surrounding Chimborazo, Cotopaxi and Antisana will be affected, because of the sudden drop in runoff (Rhoades, 2005). Additionally, the lower contribution of snowmelt may intensify the shift towards a dryer páramo 
climate, but the exact contribution of glacier runoff to the total surface runoff in the páramos is poorly documented.

Finally, the relative impact of climate change on the hydrology of the páramo, compared with land use changes, is difficult to assess. Locally, the impact of global change is probably irrelevant, compared to the impact of land use and land cover changes. But contrary to climate change, mitigation of land use changes is relatively easy. Indeed, for major cities, declaration of large areas of páramo as national parks (Chingaza near Bogotá, Cayambe-Coca near Quito, El Cajas near Cuenca), have succeeded to avoid land use changes to a certain extent (although, for instance, pine planting still occurs in El Cajas National Park). However, they are still prone to climate change. For instance, a relatively small decrease in total precipitation, or an increase in seasonality, in the páramo east of Quito, providing $85 \%$ of the city's water supply, may have a major economic impact. Currently, the economic impact of such changes is not sufficiently studied.

\section{Outlook}

From previous sections it is clear that major scientific efforts are required to bring our understanding of páramo hydrology in pace with its socio-economic importance. The most important scientific challenges for the future are:

Intensification of monitoring: The lack of reliable long term data series puts serious constraints on the study of the climate changes in the páramo. Basic meteorological data such as precipitation and temperature are mostly available. Discharge data are also present, but most monitoring stations are located in the lower areas and cover large basins. Therefore, it is difficult to separate runoff from the páramo region from runoff originating from lower areas. Furthermore, monitoring small páramo catchments would allow a better assessment of the impact of vegetation on the discharge, as small catchments are generally more homogeneous. High resolution meteorological data such as radiation, wind speed and velocity and humidity are scarce. Such data are indispensable for the further study of the role of fog and clouds in the páramo climate, which is currently poorly known. Finally, reliable long term meteorological datasets are very scarce. Most datasets contain large gaps and the accuracy is questionable.

The water balance: The water balance of the páramo is subject to large uncertainties. Especially the role of the natural páramo vegetation (both grasslands and arbustive species) in the water cycle is unknown. This role extends beyond water consumption, as evidence and observations suggest that interception and microclimate regulation may be important as well. The specific transpiration characteristics of the vegetation and the extreme weather variations may require a further search for adequate experimental procedures instead of applying classical evapotranspiration calculations based on meteorological data.

Scaling properties: While the hydrophysical soil properties are fairly well understood, a discrepancy exists between these properties and the hydrological behaviour of the páramo at catchment scale. Therefore, larger hill slope scale experiments are necessary in order to quantify the impact of preferential flow paths, heterogeneity in soil properties and topography and other aspects that are not represented at pedon scale. Because of the high organic matter content and the light bulk density, compressible soil theory may be required for an adequate description of hill slope processes (Rycroft et al., 1975; Holden and Burt, 2003a).

Hydrological modelling: Very few attempts to model the páramo hydrology are known. This is no surprise, given the scarcity of long term hydrological data sets. However, also from a conceptual viewpoint, description and modelling of the hydrological processes in these soils is particularly challenging. Many classical concepts of flow processes in rigid media cannot be applied. The high organic carbon content is responsible for strong swell and shrink properties, resulting in non-Darcian flow (Barry and Mercer, 1999; Smiles, 2000) as well as hysteresis in the water retention and the hydraulic conductivity. Furthermore, the irregular topography gives rise to perennial and ephemeral ponding, forming an additional buffering reservoir. Finally, return flow occurs more frequently than in other catchments. As a result, classical mathematical hill slope flow representations, based on the Darcy equation, may not be adequate, and non-rigid medium flow descriptions may give better results.

Adequate land management: Currently, concrete examples of land use conflicts in the páramo are rather scarce. This is primarily due to the relatively low land use pressure, and the abundant water supply up to present. But the economic development of the Andean highland goes fast, and current water supply systems are running up to their limits. Demand for additional supply systems and hydro power plants is rapidly increasing. On the other hand, páramo land is increasingly used for urban, agricultural and leisure purposes. Projections must be made to quantify the future demand for both resources, in order to ensure that appropriate measures can be taken before conflicts arise and irreversible damage occurs.

\section{Acknowledgements}

We thank the participants of the workshop "The hydrology of the Andean páramo: properties, importance and vulnerability", which was held in May, 2005 in 
Cuenca and provided valuable input for the paper. The workshop was funded by the Flemish Interuniversitary Council (VLIR) within the framework of a South Initiative project. Buytaert was funded by a K.U. Leuven postdoctoral grant (PDM).

\section{References}

Abadín, J., González-Prieto, S.J., Sarmiento, L., Villara, M.C., Carballas, T., 2002. Successional dynamics of soil characteristics in a long fallow agricultural system of the high tropical Andes. Soil Biology \& Biochemistry 34, 1739-1748.

Acosta-Solís, M., 1984. Los páramos andinos del Ecuador. Publicaciones Científicas MAS, Quito.

Allan, J.D., Brenner, A.J., Erazo, J., Fernandez, L., Flecker, A.S., Karwan, D.L., Segnini, S., Taphorn, D.C., 2002. Land use in watersheds of the Venezuelan Andes: a comparative analysis. Conservation Biology 16, 527-538.

Anonymous, 1964. Volcanic ash soils in Japan. Tech. rep.. Ministry of Agriculture and Forestry of the Japanese Government.

Ataroff, M., Rada, F., 2000. Deforestation impact on water dynamics in a Venezuelan Andean cloud forest. Ambio 29, 440-444.

Bacuilima, F.L., Bacuilima, J.C., Bermeo, W.A. 1999. Caracterización 38 de clima por microcuencas en el Austro Ecuatoriano. Master's thesis, Universidad de Cuenca, Facultad de Ingenieria, Cuenca.

Barberi, F., Coltelli, M., Ferrara, G., Innocenti, F., Navarro, J.M., Santacroce, R., 1988. Plio-quaternary volcanism in Ecuador. Geological Magazine 125, 1-14.

Baron, J.S., Hartman, M.D., Band, L.E., Lammers, R.B., 2000. Sensitivity of a high-elevation Rocky Mountain watershed to altered climate and $\mathrm{CO}_{2}$. Water Resources Research 36, 89-99.

Barry, S.I., Mercer, G.N., 1999. Flow and deformation in poroelasticity - I unusual exact solutions. Mathematical and Computer Modelling 30, 23-29.

Basile, A., De Mascellis, R., 1999. Change of hydraulic properties and solute transport parameters in volcanic ash soils after drying. In: Feyen, J., Wiyo, K. (Eds.), Modelling of transport processes in soils at various scales in time and space, pp. 267-275.

Beniston, M., 2003. Climate change in mountain regions: a review of possible impacts. Climatic Change 59, 5-31.

Bosch, J.M., Hewlett, J.D., 1982. A review of catchment experiments to determine the effect of vegetation changes on water yield and evapotranspiration. Journal of Hydrology 55, 3-23.

Brady, N.C., Weil, R.R., 1999. The nature and properties of soils, 12th ed. Prentice-hall, New Jersey.

Bruijnzeel, L.A., 2004. Hydrological functions of tropical forests: not seeing the soil for the trees? Agriculture, Ecosystems and Environment 104, 185-228.

Bruijnzeel, L.A., Proctor, J., 1995. Hydrology and biogeochemistry of tropical montane cloud forests: what do we really know? In: Hamilton, L.S., Juvik, J.O., Scatena, F.N. (Eds.), Tropical montane cloud forests. Springer-Verlag, New York, pp. 38-78.

Buytaert, W. 2004. The properties of the soils of the south Ecuadorian páramo and the impact of land use changes on their hydrology. Ph.D. thesis, Faculty of Agricultural and Applied Biological Sciences, Katholieke Universiteit Leuven.

Buytaert, W., Deckers, J., Dercon, G., De Bièvre, B., Poesen, J., Govers, G., 2002. Impact of land use changes on the hydrological properties of volcanic ash soils in South Ecuador. Soil Use and Management 18, 94-100.
Buytaert, W., De Bièvre, B., Wyseure, G., Deckers, J., 2004. The use of the linear reservoir concept to quantify the impact of land use changes on the hydrology of catchments in the Ecuadorian Andes. Hydrology and Earth System Sciences 8, 108-114.

Buytaert, W., De Bièvre, B., Wyseure, G., Deckers, J., 2005a. The effect of land use changes on the hydrological behaviour of Histic Andosols in south Ecuador. Hydrological Processes 19, 3985-3997.

Buytaert, W., Iñiguez, V., Celleri, R., De Bièvre, B., Wyseure, G., Deckers, J., 2005b. Analysis of the water balance of small páramo catchments in south Ecuador. Proceedings of the International Conference on Headwater Control VI: Hydrology, Ecology and Water Resources in Headwaters. Bergen, Norway, 20-23 June 2005, CDROM.

Buytaert, W., Sevink, J., Leeuw, B.D., Deckers, J., 2005c. Clay mineralogy of the soils in the south Ecuadorian páramo region. Geoderma 127, 114-129.

Byers, A.C., 2000. Contemporary landscape change in the Huascarán National Park and Buffer Zone, Cordillera Blanca, Peru. Mountain Research and Development 20, 52-63.

Calder, I.R., 1998. Water-resource and land-use issues. SWIM Paper, vol. 3. International Water Management Institute, Colombo Sri Lanka.

Castaño, C., 2002. Páramos y ecosistemas alto andinos de Colombia en condición hotspot y global climatic tensor. IDEAM, Bogotá.

Cavelier, J., Aide, T.M., Santos, C., Eusse, A.M., Dupuy, J.M., 1998. The savannization of moist forests in the Sierra Nevada de Santa Marta, Colombia. Journal of Biogeography 25, 901-912.

Charman, D., 2002. Peatlands and Environmental Change. John Wiley and Sons, New York, NY.

Chepstow-Lusty, A.J., Bennett, K.D., Swistur, V.R., Kendall, A., 1996. 4000 years of human impact and vegetation change in the central Peruvian Andes — with events parallelling the Maya record? Antiquity 70, 824-833.

Cleef, A.M., 1981. The vegetation of the páramos of the Colombian Cordillera Oriental. Dissertationes Botanicae 61, 1-320.

Clermont-Dauphin, C., Cabidoche, Y.M., Meynard, J.M., 2004. Effects of intensive monocropping of bananas on properties of volcanic soils in the uplands of the French West Indies. Soil Use and Management 20, 105-113.

Colmet-Daage, F., Cucalon, F., Delaune, M., Gautheyrou, J., Gautheyrou, M., Moreau, B., 1967. Caractéristiques de quelques sols d'Equateur dérivés de cendres volcaniques. II. Conditions de formation et d'évolution. Cahiers ORSTOM. Série Pédologie 5, 353-392.

De Bièvre, B. 2002. Water demand-supply and administrative management in medium sized irrigation schemes in the sierra of Ecuador. Ph.D. thesis, Katholieke Universiteit Leuven.

de Noni, G., Prat, C., Quantin, P., Viennot, M., Zebrowski, C., 2000. Erosion et conservation, après récupération, des sols volcaniques indurés de l'Equateur et du Mexique. Études et Gestion des Sols 7, $25-36$.

Dercon, G., Bossuyt, B., De Bièvre, B., Cisneros, F., Deckers, J., 1998. Zonificación agroecológica del Austro Ecuatoriano. U Ediciones, Cuenca, Ecuador

Dinerstein, E., Olson, D.M., Graham, D.J., Webster, A.L., Primm, S.A., Bookbinder, M.P., Ledec, G., 1995. A conservation assessment of the terrestrial ecoregions of Latin America and the Caribbean. The World Bank, Washington, D.C.

Dorel, M., Roger-Estrade, J., Manichon, H., Delvaux, B., 2000. Porosity and soil water properties of Caribbean volcanic ash soils. Soil Use and Management 16, 133-140.

Etter, A., Villa, L.A., 2000. Andean forests and farming systems in part of the Eastern Cordillera (Colombia). Mountain Research and Development 20, 236-245. 
FAO, 2000. Irrigation in Latin America and the Caribbean in figures. No. 20 in Water Report. FAO.

FAO/ISRIC/ISSS, 1998. World Reference Base for Soil Resources. No. 84 in World Soil Resources Reports. FAO, Rome.

Farley, K.A., Kelly, E.F., 2004. Effects of afforestation of a páramo grassland on soil nutrient status. Forest Ecology and Management 195, 271-290.

Farley, K.A., Kelly, E.F., Hofstede, R.G.M., 2004. Soil organic carbon and water retention after conversion of grasslands to pine plantations in the Ecuadorian Andes. Ecosystems 7, 729-739.

Foster, P., 2001. The potential negative impacts of global climate change on tropical montane cloud forests. Earth-Science Reviews $55,73-106$.

Francou, B., Ramirez, E., Cácerez, B., Mendoza, J., 2000. Glaciar evolution in the tropical Andes during the last decades of the 20th century: Chacaltaya, Bolivia and Antisana, Ecuador. Ambio 29, 416-422.

Garcia, M., Raes, D., Allen, R., Herbas, C., 2004. Dynamics of reference evapotranspiration in the Bolivian highlands (altiplano). Agricultural and Forest Meteorology 125, 67-82.

Giorgi, F., Bi, X., 2005. Updated regional precipitation and temperature changes for the 21 century from ensembles of recent aogcm simulations. Geophysical Research Letters 32, L21715.

Golchin, A., Baldock, J.A., Clarke, P., Higashi, T., Oades, J.M., 1997. The effects of vegetation and burning on the chemical composition of soil organic matter of a volcanic ash soil by C NMR spectroscopy. II. Density fractions. Geoderma 76, 175-192.

Gonzalez, J., 2000. Monitoring cloud interception in a tropical montane cloud forest in the south western Colombian Andes. Advances in Environmental Monitoring and Modelling 1, 97-117.

Gutiérrez, H., 2002. Aproximación a un modelo para la evaluación de la vulnerabilidad de las cuberturas vegetales de Colombia ante un posible cambio climático utilizando sistemas de información geográfica SIG con énfasis en la vulnerabilidad de las cuberturas nival y de páramo de Colombia. In: Castaño, C. (Ed.), Páramos y ecosistemas alto andinos de Colombia en condición hotspot y global climatic tensor. IDEAM, Bogotá, pp. 335-377.

Hansen, B., Rodbell, D., Seltzer, G., León, B., Young, K., Abbott, M., 2003. Late-glacial and Holocene vegetational history from two sites in the western cordillera of southwestern Ecuador. Palaeogeography, Palaeoclimatology, Palaeoecology 194, 79-108.

Harden, C.P., 2001. Soil erosion and sustainable mountain development. Mountain Research and Development 21 (1), 77-83.

Hedberg, O., 1964. Features of Afroalpine plant ecology. Acta Phytogeographica Suecica 49, 1-144.

Hedberg, O., 1992. Afroalpine vegetation compared to páramo: convergent adaptations and divergent differentiation. In: Balslev, H., Luteyn, J.L. (Eds.), Páramo: an Andean ecosystem under human influence. Academic Press, London, pp. 15-30.

Herrera, W., 2005. El clima de los páramos de Costa Rica. In: Kappelle, M., Horn, S.P. (Eds.), Páramos de Costa Rica. Instituto Nacional de Biodiversidad INBio, pp. 113-160.

Hincapié, J.C.A., Castillo, C.B., Argüello, S.C., Aguilera, D.P.R., Holguín, F.S., Triana, J.V., Lopera, A., 2002. Transformación y cambio en el uso del suelo en los páramos de Colombia en las últimas décadas. In: Castaño, C. (Ed.), Páramos y ecosistemas alto andinos de Colombia en condición hotspot y global climatic tensor. IDEAM, Bogotá, pp. 211-333.

Hofstede, R.G.M. 1995a. Effects of burning and grazing on a Colombian páramo ecosystem. Ph.D. thesis, Universiteit van Amsterdam.

Hofstede, R.G.M., 1995b. The effects of grazing and burning on soil and plant nutrient concentrations in Colombian páramo grasslands. Plant and Soil 173, 111-132.
Hofstede, R.G.M., 1995c. Effects of livestock farming and recommendations for management and conservation of páramo grasslands (Colombia). Land Degradation \& Rehabilitation 6, 133.

Hofstede, R.G.M., 1995d. Vegetative structure, microclimate, and leaf growth of a páramo tussock grass species, in undisturbed, burned and grazed conditions. Vegetatio 119, 53-65.

Hofstede, R.G.M., Mondragon, M.X., Rocha, C.M., 1995. Biomass of grazed, burned, and undistributed páramo grasslands, Colombia. 1. Aboveground vegetation. Arctic and Alpine Research 27, 1-12.

Hofstede, R., Segarra, P., Mena, P.V., 2003. Los Páramos del Mundo. Global Peatland Initiative/NC-IUCN/EcoCiencia, Quito.

Holden, J., Burt, T.P., 2002. Laboratory experiments on drought and runoff in blanket peat. European Journal of Soil Science 53, 675-689.

Holden, J., Burt, T.P., 2003a. Hydraulic conductivity in upland blanket peat: measurement and variability. Hydrological Processes 17, 1227-1237.

Holden, J., Burt, T.P., 2003b. Hydrological studies on blanket peat: the significance of the acrotelm-catotelm model. Journal of Ecology $91,86-102$.

Hungerbühler, D., Steinmann, M., Winkler, W., Seward, D., Eguez, A., Peterson, D.E., Helg, U., Hammer, C., 2002. Neogene stratigraphy and Andean geodynamics of southern Ecuador. Earth-Science Reviews 57, 75-124.

IDEAM, 2001. Colombia, Primera Comunicación Nacional ante la Convención Marco de las Naciones Unidos sobre el Cambio Climatico. IDEAM, Bogota.

IPCC, 2001. Climate Change 2001: Impacts, Adaptation and Vulnerability. Cambridge University Press, Cambridge.

IUCN, 2002. High Andean wetlands. Tech. rep. IUCN, Gland, Switzerland.

Kappelle, M., Horn, S.P., 2005. Páramos de Costa Rica. Instituto Nacional de Biodiversidad INBio.

Keating, P.L., 1998. Effects of anthropogenic disturbances on páramo vegetation in Podocarpus National Park, Ecuador. Physical Geography 19, 221-238.

Kehrer, W., der Kaaden, G.V., 1979. Notes on the geology of Ecuador with special reference to the western cordillera. Geologisches Jahrbuch. Reihe B 35.

Legesse, D., Vallet-Coulomb, C., Gasse, F., 2003. Hydrological response of a catchment to climate and land use changes in tropical Africa: case study south central Ethiopia. Journal of Hydrology 275, 67-85.

Liniger, H.P., Weingartner, R., Grosjean, M., 1998. Mountains of the World: Water Towers for the 21st Century. Mountain Agenda, University of Berne, Switzerland.

Luteyn, J.L., 1992. Páramos: why study them? In: Balslev, H., Luteyn, J.L. (Eds.), Páramo: an Andean ecosystem under human influence. Academic Press, London, pp. 1-14.

Luteyn, J.L., 1999. Páramos: A Checklist of Plant Diversity, Geographical Distribution, and Botanical Literature. The New York Botanical Garden Press, New York.

Luteyn, J.L., Cleef, A.M., Rangel, O., 1992. Plant diversity in páramo: towards a checklist of páramo plants and generic flora. In: Balslev, H., Luteyn, J.L. (Eds.), Páramo: an Andean ecosystem under human influence. Academic Press, London, pp. 71-84.

Mena, P., Medina, G., 2001. Los páramos en el Ecuador. In: Mena, P., Medina, G., Hofstede, R. (Eds.), Los páramos del Ecuador. Proyecto Páramo, Quito, pp. 1-24.

Messerli, B., Grosjean, M., Vuille, M., 1997. Water availability, protected areas and natural resources in the Andean desert altiplano. Mountain Research and Development 17, 229-238.

Messerli, B., Viviroli, D., Weingartner, R., 2004. Mountains of the world: vulnerable water towers for the 21 st century. Ambio Special Report 13, 29-34. 
Meybeck, M., 2004. The global change of continental aquatic systems: dominant impacts of human activities. Water Science and Technology 49, 73-83.

Meybeck, M., Vörösmarty, C.J., Schulze, R.E., Becker, A., 2005. Scaling relative responses 1 of terrestrial aquatic systems to global changes. In: Kabat, P., Claussen, M., Dirmeyer, P.A., Gash, J.H.C., de Guenni, L.B., Meybeck, M., Vörösmarty, C.J., Hutjes, R.W.A., Lütkemeier, S. (Eds.), Vegetation, Water, Humans and the Climate: a New Perspective on an Interactive System. Springer, Verlag IGBP Synthesis Series, pp. 455-456.

Molinillo, M., Monasterio, M., 1997. Pastoralism in páramo environments: practices, forage and impact on vegetation in the Cordillera de Merida, Venezuela. Mountain Research and Development 17, 197-211.

Mwendera, E.J., 1994. Effect on the water yield of the Luchelemu catchment in Malawi of replacing indigenous grasses with timber plantations. Forest Ecology and Management 65, 75-80.

Nanzyo, M., Shoji, S., Dahlgren, R., 1993. Volcanic Ash Soils: Genesis, Properties and Utilisation. Developments in Soil Science, vol. 21. Elsevier, Amsterdam.

Neall, V.E., 1985. Properties of andisols important to pasture and horticulture. In: Beinroth, F.H., Luzio, W.L., Maldonado, F.P., Eswaran, H. (Eds.), Proceedings of the Sixth International Soil Classification Workshop, Chile and Ecuador. Part I: papers. Sociedad Chilena de la Ciencia del Suelo, Santiago, Chile, pp. 109-189.

Pels, B., Verwey, P.A., 1992. Burning and grazing in a bunchgrass páramo ecosystem: vegetation dynamics described by a transition model. In: Balslev, H., Luteyn, J.L. (Eds.), Páramo: an Andean ecosystem under human influence. Academic Press, London, pp. 243-263.

Pérez, F.L., 1984. Striated soil in an Andean páramo of Venezuela: its origin and orientation. Arctic and Alpine Research 16, 277-289.

Pérez, F.L., 1991. Particle sorting due to off-road vehicle traffic in a high Andean páramo. Catena 18, 239-254.

Pérez, F.L., 1992. Processes of turf exfoliation (rabenabschälung) in the high Venezuelan Andes. Zeitschrift Für Geomorphologie N.F. $36,81-106$.

Piccolo, A., Mbagwu, J.S.C., 1999. Role of hydrophobic components of soil organic matter in soil aggregate stability. Soil Science Society of America Journal 63, 1801-1810.

Podwojewski, P., Germain, N., 2005. Short-term effects of management on the soil structure in a deep tilled hardened volcanic-ash soil (cangahua) in Ecuador. European Journal of Soil Science 56, 39-51.

Podwojewski, P., Poulenard, J., Zambrana, T., Hofstede, R., 2002. Overgrazing effects on vegetation cover and properties of volcanic ash soil in the páramo of Llangahua and La Esperanza (Tungurahua, Ecuador). Soil Use and Management 18, 45-55.

Poulenard, J. 2000. Les sols des páramos d'Equateur sur couverture pyroclastique. diversité, génèse et propriétés physiques. Ph.D. thesis, Université Henry Poincare - Nancy I.

Poulenard, J., Podwojewski, P., Janeau, J.L., Collinet, J., 2001. Runoff and soil erosion under rainfall simulation of andisols from the Ecuadorian páramo: effect of tillage and burning. Catena 45, 185-207.

Poulenard, J., Bartoli, F., Burtin, G., 2002. Shrinkage and drainage in aggregates of volcanic soils: a new approach combining mercury porosimetry and vacuum drying kinetics. European Journal of Soil Science 53, 563-574.

Poulenard, J., Podwojewski, P., Herbillon, A.J., 2003. Characteristics of nonallophanic andisols with hydric properties from the Ecuadorian páramos. Geoderma 117, 267-281.

Poulenard, J., Michel, J.C., Bartoli, F., Portal, M., Podwojewski, P., 2004. Water repellency of volcanic ash soils from Ecuadorian páramo: effect of water content and characteristics of hydrophobic organic matter. European Journal of Soil Science 55, 487-496.
Price, J.S., Waddington, J.M., 2000. Advances in Canadian wetland hydrology and biogeochemistry. Hydrological Processes 14, 1579-1589.

PROMAS, 2004. Efectos de la cobertura vegetal en la regulación hidrológica de microcuencas de páramo. Tech. rep. Universidad de Cuenca.

Rangel, C. 2000. La región de vida paramuna. Colombia Diversidad Biótica III. Universidad Nacional de Colombia, Instituto de Ciencias Naturales, Bogotá.

Rhoades, R., 2005. A vanishing Andean glacier: History, local perceptions, and societal impacts of climate change in Cotacachi, Ecuador. Proceedings of the conference on Global Change in Mountain Regions, 2-6 October 2005, Perth, UK.

Rossel, F., 1997. Influencia de El Niño sobre los regimenes hidropluviometricos del Ecuador. Series INSEQ, vol. 18. INAMHI, Quito.

Rossenaar, A.J.G.A., Hofstede, R.G.M., 1992. Effects of burning and grazing on root biomass in the páramo ecosystem. In: Balslev, H., Luteyn, J.L. (Eds.), Páramo: an Andean ecosystem under human influence. Academic Press, London, pp. 211-213.

Rousseaux, J.M., Warkentin, B.P., 1976. Surface properties and forces holding water in allophane soils. Soil Science Society of America Journal 40, 446-451.

Rowe, L.K., Pearce, A.J., O’Loughlin, C.L., 1994. Hydrology and related changes after harvesting native forest catchments and establishing Pinus radiata plantations. Part I. Introduction to study. Hydrological Processes 8, 263-279.

Rycroft, D.W., Williams, D.J.A., Ingram, H.A.P., 1975. The transmission of water through peat: I. Review. Journal of Ecology 63, 535-556.

Sakalauskas, K.M., Costa, J.L., Laterra, P., Higaldo, L., Aguirrezabal, L.A.N., 2001. Effects of burning on soil-water content and water use in a Paspalum quadrifarium grassland. Agricultural Water Management 50, 97-108.

Sarmiento, G., 1986. Ecological features of climate in high tropical mountains. In: Vuilleumier, F., Monasterio, M. (Eds.), High altitude tropical biogeography. Oxford University Press, Oxford, pp. 11-45.

Sarmiento, L., 2000. Water balance and soil loss under long fallow agriculture in the Venezuelan Andes. Mountain Research and Development 20, 246-253.

Sarmiento, F.O., 2002. Anthropogenic change in the landscapes of highland Ecuador. The Geographical Review 92, 213-234.

Sauer, W., 1957. El mapa geologico del Ecuador. Editorial Universitaria, Quito.

Schjellerup, I., 1992. Pre-Columbian field systems and vegetation in the jalca of northeastern Peru. In: Balslev, H., Luteyn, J.L. (Eds.), Páramo: an Andean ecosystem under human influence. Academic Press, London, pp. 137-149.

Schmidt, A.M., Verweij, P.A., 1992. Forage intake and secondary production in extensive livestock systems in páramo. In: Balslev, H., Luteyn, J.L. (Eds.), Páramo: an Andean ecosystem under human influence. Academic Press, London, pp. 197-210.

Sémiond, H., Francou, B., Ayabaca, E., de la Cruz, A., Chango, R., 1998. El glaciar 15 del Antisana (Ecuador). Tech. rep. ORSTOM, Quito.

Shepherd, T.G., Saggar, S., Newman, R.H., Ross, C.W., Dando, J.L., 2001. Tillage-induced changes to soil structure and organic carbon fractions in New Zealand soils. Australian Journal of Soil Research 39, 465-489.

Shoji, S., Fujiwara, Y., 1984. Active aluminum and iron in the humus horizons of andosols from northeastern Japan: their forms, properties, and significance in clay weathering. Soil Science 137 (4), 216-226.

Smiles, D.E., 2000. Hydrology of swelling soils: a review. Australian Journal of Soil Research 38, 501-521.

Soil Survey Staff, 2003. Keys to Soil Taxonomy, Ninth ed. United States Department of Agriculture. 
Southgate, D., Macke, R., 1989. The downstream benefits of soil conservation in third world hydroelectric watersheds. Land Economics 65, 38-48.

Still, C.J., Foster, P.N., Schneider, S.H., 1999. Simulating the effects of climate change on tropical montane cloud forests. Nature 398, 608-610

Thompson, L.G., Mosley-Thompson, E., Henderson, K.A., 2000. Icecore palaeoclimate records in tropical South America since the last glacial maximum. Journal of Quaternary Science 15, 377-394.

Timbe, E. 2004. Disgregacion temporal de datos diarios de precipitacion en microcuencas de páramo. Master's thesis, Universidad de Cuenca.

Tisdall, J.M., Oades, J.M., 1982. Organic matter and water-stable aggregates in soils. Journal of Soil Science 33, 141-163.

Tucker, G.E., Slingerland, R., 1997. Drainage basin responses to climate change. Water Resources Research 33, 2031-2047.

UAESPNN, 2000. Plan estratégico y de manejo para el Parque Nacional Natural Chingaza y su zona de influencia. Ministerio del Medio Ambiente, Republica de Colombia.

Valat, B., Jouany, C., Riviere, L.M., 1991. Characterization of the wetting properties of air-dried peats and composts. Soil Science 152 (2), 100-107.

van der Hammen, T., Hooghiemstra, H., 2000. Neogene and Quaternary history of vegetation, climate, and plant diversity in Amazonia. Quaternary Science Reviews 19, 725-742.

Van der Hammen, T., Caicedo, J.D.P., Gutiérrez, H., Alarcón, J.C., 2002. El cambio global y los ecosistemas de alta montaña de Colombia. In: Castaño, C. (Ed.), Páramos y ecosistemas alto andinos de Colombia en condición hotspot y global climatic tensor. IDEAM, Bogotá, pp. 163-209.

Vargas, O.R., Zuluaga, S., 1986. Clasificación y ordenación de comunidades vegetales de páramo. Perez-Arbelaezia 1 (2), $125-143$.

Veneklaas, E., Zagt, R., Leerdam, A.V., Ek, R.V., Broekhoven, G., Genderen, M.V., 1990. Hydrological properties of the epiphyte mass of a montane tropical rain forest, Colombia. Vegetatio 89 , 183-192.

Verweij, P.A., Budde, P.E., 1992. Burning and grazing gradients in páramo vegetation: initial ordination analyses. In: Balslev, H., Luteyn, J.L. (Eds.), Páramo: an Andean ecosystem under human influence. Academic Press, London, pp. 177-195.

Viviroli, D., Weingartner, R., 2004. The hydrological significance of mountains: from regional to global scale. Hydrology and Earth System Sciences 8, 1016-1029.

Viviroli, D., Weingartner, R., Messerli, B., 2003. Assessing the hydrological significance of the world's mountains. Mountain Research and Development 23, 32-40.

Vuille, M., Bradley, R.S., Keimig, F., 2000. Climate variability in the Andes of Ecuador and its relation to tropical Pacific and Atlantic sea surface temperature anomalies. Journal of Climate 13, $2520-2535$.

Wada, K., 1985. The distinctive properties of andosols. Advances in Soil Science 2, 174-223.

Waddington, J.M., Roulet, N.T., 2000. Carbon balance of a boreal patterned peatland. Global Change Biology 6, 87-97.

Warkentin, B.P., Maeda, T., 1980. Physical and mechanical characteristics of andisols. In: Theng, B.K.G. (Ed.), Soils with variable charge. New Zealand Society of Soil Science, pp. 281-302.

Wille, M., Hooghiemstra, H., Hofstede, R., Fehse, J., Sevink, J., 2002. Upper forest line reconstruction in a deforested area in northern Ecuador based on pollen and vegetation analysis. Journal of Tropical Ecology 18, 409-440.

Winckell, A., Zebrowski, C., Delaune, M., 1991. Evolution du modèle Quaternaire et des formations superficielles dans les Andes de l’Équateur. Géodynamique 6, 97-117.

Zehetner, F., Miller, W.P., West, L.T., 2003. Pedogenesis of volcanic ash soils in Andean Ecuador. Soil Science Society of America Journal 67, 1797-1809. 